2013s-41

\title{
Identifying Banking Crises Using Money Market Pressure: New Evidence For A Large Set of Countries
}

Zhongbo Jing, Jakob de Haan, Jan Jacobs, Haizhen Yang

Série Scientifique
Scientific Series

Montréal

Octobre/October 2013

(C) 2013 Zhongbo Jing, Jakob de Haan, Jan Jacobs, Haizhen Yang. Tous droits réservés. All rights reserved. Reproduction partielle permise avec citation du document source, incluant la notice (C)

Short sections may be quoted without explicit permission, if full credit, including (C) notice, is given to the source.
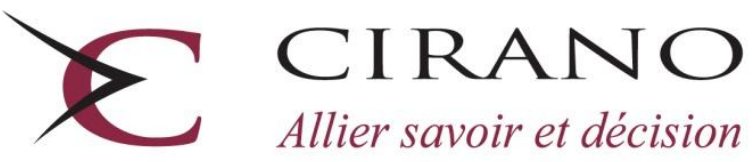

Allier savoir et décision

Centre interuniversitaire de recherche en analyse des organisations 


\section{CIRANO}

Le CIRANO est un organisme sans but lucratif constitué en vertu de la Loi des compagnies du Québec. Le financement de son infrastructure et de ses activités de recherche provient des cotisations de ses organisations-membres, d'une subvention d'infrastructure du Ministère de l'Enseignement supérieur, de la Recherche, de la Science et de la Technologie, de même que des subventions et mandats obtenus par ses équipes de recherche.

CIRANO is a private non-profit organization incorporated under the Québec Companies Act. Its infrastructure and research activities are funded through fees paid by member organizations, an infrastructure grant from the Ministère de l'Enseignement supérieur, de la Recherche, de la Science et de la Technologie, and grants and research mandates obtained by its research teams.

\section{Les partenaires du CIRANO}

\section{Partenaire majeur}

Ministère de l'Enseignement supérieur, de la Recherche, de la Science et de la Technologie

Partenaires corporatifs

Autorité des marchés financiers

Banque de développement du Canada

Banque du Canada

Banque Laurentienne du Canada

Banque Nationale du Canada

Banque Scotia

Bell Canada

BMO Groupe financier

Caisse de dépôt et placement du Québec

Fédération des caisses Desjardins du Québec

Financière Sun Life, Québec

Gaz Métro

Hydro-Québec

Industrie Canada

Investissements PSP

Ministère des Finances et de l'Économie

Power Corporation du Canada

Rio Tinto Alcan

State Street Global Advisors

Transat A.T.

Ville de Montréal

\section{Partenaires universitaires}

École Polytechnique de Montréal

École de technologie supérieure (ÉTS)

HEC Montréal

Institut national de la recherche scientifique (INRS)

McGill University

Université Concordia

Université de Montréal

Université de Sherbrooke

Université du Québec

Université du Québec à Montréal

Université Laval

Le CIRANO collabore avec de nombreux centres et chaires de recherche universitaires dont on peut consulter la liste sur son site web.

Les cahiers de la série scientifique (CS) visent à rendre accessibles des résultats de recherche effectuée au CIRANO afin de susciter échanges et commentaires. Ces cahiers sont écrits dans le style des publications scientifiques. Les idées et les opinions émises sont sous l'unique responsabilité des auteurs et ne représentent pas nécessairement les positions du CIRANO ou de ses partenaires.

This paper presents research carried out at CIRANO and aims at encouraging discussion and comment. The observations and viewpoints expressed are the sole responsibility of the authors. They do not necessarily represent positions of CIRANO or its partners. 


\title{
Identifying Banking Crises Using Money Market Pressure: New Evidence For A Large Set of Countries
}

\author{
Zhongbo Jing *, Jakob de Haan", Jan Jacobs ${ }^{\dagger}$, Haizhen Yang ${ }^{\S}$
}

\section{Résumé/abstract}

We construct a money market pressure index based on central bank reserves and the short-term nominal interest rate to identify banking crises, thereby extending the index proposed by Von Hagen and Ho (2007). We compare the crises identified by both indices with banking crises according to the benchmark of Laeven and Valencia (2010). Both indices identify more crises than these benchmarks. The crises identified by our index are more in line with the benchmark than the crises identified by the Von Hagen and Ho index, while our index also gives fewer false signals.

Mots clés/keywords : banking crises, money market pressure index.

Codes JEL : C43, E44, G21

\footnotetext{
* University of Groningen, Groningen, the Netherlands; School of Management, University of Chinese Academy of Sciences, Beijing, China; Research Center of Fictitious Economy \& Data Science, CAS, Beijing, China. ${ }^{\dagger}$ Corresponding author. University of Groningen, Groningen, the Netherlands; De Nederlandsche Bank, Amsterdam, the Netherlands; CESifo, Munich, Germany. Email: jakob.de.haan@ @rug.nl.

University of Groningen, Groningen, the Netherlands; CAMA, Australian National University, Canberra, Australia; CIRANO, Montréal, Canada; University of Tasmania, Australia.

${ }^{\S}$ School of Management, University of Chinese Academy of Sciences, Beijing, China; Research Center of Fictitious Economy \& Data Science, CAS, Beijing, China.
} 


\section{Introduction}

Since the collapse of the Bretton Woods system, the frequency of financial crises has doubled (Bordo et al., 2001). Notably after the financial liberalization during the 1990s, the intensity of financial crises has increased. Recent research suggests that financial crises may have a permanent effect on potential output (Furceria et al., 2012).

In general, three types of financial crises may be distinguished: currency crises, banking crises and debt crises. Compared to other types, banking crises have a more serious impact on the economy (Hutchison et al., 2005). It is therefore important to prevent banking crises and to reduce the costs of banking crises once they occur (Caprio and Klingebiel 1996; Kaminsky and Reinhart 1999; Frydl 1999; Demirgüç-Kunt and Detragiache 1998, 2005; Duttagupta and Cashin 2008; and Davis et al. 2008a, 2008b).

A serious methodological challenge which researchers face is the identification of (systemic) banking crises. Most studies identify a (systemic) banking crisis based on exceptional events or policy interventions, such as bank closures, deposit freezes and government rescues (cf. Laeven and Valencia, 2008; 2010; 2013; and Reinhart and Rogoff, 2009). However, Von Hagen and Ho (2007) argue that this events methodology may be biased for several reasons. First, such interventions may refer to a few banks having problems rather than the whole banking sector. Second, it is hard to determine whether a particular policy intervention is taken because of a systemic banking crisis. Third, policy interventions mostly occur when a crisis has a significant impact on the financial system or the economy, which implies that the start of the banking crisis may 
be identified too late. Finally, not each crisis leads to government interventions as central banks sometimes solve financial problems successfully. Therefore, there may be a selection bias when banking crises are identified based on interventions by government authorities. ${ }^{1}$

Drawing on the reasoning of Eichengreen et al. (1996a, 1996b), Von Hagen and Ho (2007) propose an index to identify banking crises based on money market pressure (which will be discussed in more detail in section 2). A monetary pressure index cannot offset all drawbacks of the events methodology, but advantages of a money market pressure index include that it is less subjective, available at a higher frequency and timelier. Although the Von Hagen-Ho index is very innovative, we argue that it can be improved upon by using nominal instead of real interest rates and by weighting its components differently. We propose a modified monetary pressure crises index to identify banking crises and compare it to Von Hagen and Ho's index. We construct the index for a much larger sample of countries than Von Hagen and Ho (2007). For comparison purposes we use the Laeven-Valencia (2010) database of banking crises, which is based on the events methodology. In our analysis we presume that this benchmark correctly identifies crises, even though there are good reasons to suspect that especially the timing of crises according to these benchmarks may be wrong. In our

\footnotetext{
${ }^{1}$ Likewise, Boyd et al. (2009) argue that the banking crisis indicators they examine-including those of Reinhart and Rogoff (2009) and Laeven and Valencia (2008)—actually measure lagged government responses to systemic bank shocks, rather than the occurrence of crises per se. After we had finished the research reported in this paper, Laeven and Valencia (2013) published an update of their dataset, which deviates sometimes substantially from their earlier dataset, further illustrating the intricacies of the events methodology.
} 
comparison we take this timing issue into account by considering a signal given by the monetary pressure index to be correct also if it is two years earlier or one year later than the crisis period identified by the benchmarks. It turns out that the crises identified by our index are more in line with those of Laeven and Valencia (2010), while our index also identifies fewer banking crises that are not listed in the benchmark than the index of Von Hagen and Ho. This conclusion is robust when we use different samples or other becnhmarks. Our research also shows that money market pressure indexes, be it the original index of Von Hagen and Ho (2007) or our index, indicate many more banking crises than the events methodology. Further analysis shows that when our index gives a false signal (i.e. there is no crisis according to the benchmarks) there are frequently indications of financial stress.

The rest of the paper is organized as follows. Section 2 reviews previous research on identifying banking crises. Section 3 discusses the index proposed by Von Hagen and Ho (2007) and presents our proposed amendments. Section 4 describes the data and criteria for identifying banking crises. Section 5 compares crises identified by both indexes with crises according to the benchmarks, while section 6 offers a sensitivity analysis. Finally, section 7 concludes.

\section{Identifying banking crises}

\subsection{The events method}

The events method identifies banking crises based on the occurrence of certain events, such as bank runs, closures, mergers and government interventions (Demirgüç-Kunt 
and Detragiache, 1998). Caprio and Klingebiel (1996) adopt information from supervisors and country experts to identify banking crises. In its World Economic Outlook, the IMF (1998, p.76) extends Caprio and Klingebiel's scheme and identifies a banking crisis as a situation in which actual or potential bank runs and failures lead banks to suspend the internal convertibility of their liabilities or compel the government to provide large-scale interventions in the banking sector.

Demirgüç-Kunt and Detragiache $(1998,2002,2005)$ identify an event as a crisis if at least one of the following conditions holds:

(i) the ratio of non-performing assets to the banking system's total assets exceeds $10 \%$;

(ii) the cost of the government's rescue operation is at least $2 \%$ of GDP;

(iii) banking sector problems result in a large-scale nationalization of banks;

(iv) extensive bank runs take place or emergency measures such as deposit freezes, prolonged bank holidays, or generalized deposit guarantees are enacted by the government in response to the crisis.

Laeven and Valencia $(2008,2010)$ adopt a somewhat different definition to identify banking crises. Laeven and Valencia (2008, p. 5) define a systemic banking crisis as an event where a "country's corporate and financial sectors experience a large number of defaults and financial institutions and corporations face great difficulties repaying contracts on time. This situation may be accompanied by depressed asset prices (such as equity and real estate prices) on the heels of run-ups before the crisis, sharp increases in real interest rates, and a slowdown or reversal in capital flows. In 
some cases, the crisis is triggered by depositor runs on banks, though in most cases it is a general realization that systemically important financial institutions are in distress."

As pointed out in the Introduction, Von Hagen and Ho (2007) argue that the events method has several shortcomings. Therefore, they suggest an index based on pressure in the money market to identify banking crises.

\subsection{Money market pressure index}

The basic idea of the money market pressure index of Von Hagen and Ho (2007) is that in a crisis the banking sector will face difficulties, such as an increase in non-performing assets, withdrawals of deposits, and drying up of inter-bank lending, which will lead to a sharp increase in banks' demand for central bank liquidity. The central bank will react to this increased demand in two ways. If central bank reserves are the operating target of monetary policy, the supply of reserves will be constant and the short-term interest rate will rise. Otherwise, the central bank will sustain the level of the short-term interest rate and inject additional reserves into the banking sector. Thus, a banking crisis is generally characterized by a sharp increase of short-term interest rates, the stock of central bank reserves, or both.

Based on this logic, Von Hagen and Ho (2007) propose the following money market pressure index (MPI):

$$
M P I_{t}=\frac{\Delta \gamma_{t}}{\sigma_{\Delta \gamma}}+\frac{\Delta r_{t}}{\sigma_{\Delta r}}
$$


where $\Delta$ is the difference operator, $\gamma$ is the ratio of central bank reserves to total bank deposits, $r$ is the short-term interest rate, while $\sigma_{\Delta \gamma}$ and $\sigma_{\Delta r}$ are the standard deviations of $\Delta \gamma$ and $\Delta r$, respectively.

In identifying a banking crisis, Von Hagen and Ho (2007) apply two criteria. First, the MPI needs to exceed the 98.5 percentile of the sample distribution for the country under consideration. Second, the increase of the MPI from the previous period should at least be $5 \%$. The first condition ensures that only exceptional events are treated as crises, and the second one is applied to avoid signaling crises in countries that did not experience a banking crisis. ${ }^{2}$ Von Hagen and Ho quantify these criteria by selecting the combination of parameters that can best identify crises as listed by Caprio and Klingebiel (1996).

\section{Modification of the money market pressure index}

The money market pressure index constructed by Von Hagen and Ho (2007) is less subjective than the events methods. However, the index has some drawbacks as well. First, Von Hagen and Ho use the short-term real interest rate in their index instead of the short-term nominal interest rate while normally rising nominal rates indicate liquidity shortages in the money market. If the real interest rate decreases due to higher inflation, the money market pressure index will go down thereby wrongly indicating that the probability of a banking crisis has decreased. Previous research suggests that, if anything, inflation has a positive impact on banking crises (cf. Demirgüç-Kunt and

\footnotetext{
${ }^{2}$ These two criteria are similar to the extreme-value based identification of currency crises studied by Lestano and Jacobs (2007).
} 
Detragiache 1998, 2002) and not a negative impact as implied by the index of Von Hagen and Ho.

Second, due to data limitations Von Hagen and Ho calculate standard deviations over the whole sample period thereby ignoring possible changes in monetary regimes. As we have sufficiently long samples—each country's sample exceeds 9 years-we apply rolling 24-month periods to calculate standard deviations. ${ }^{3}$ As the ratio of central bank reserves to total bank deposits $\gamma$ may be constant for a long time (which is the case in some countries) so that the standard deviation of $\Delta \gamma$ is equal to zero, the MPI index cannot be constructed. ${ }^{4}$ Even if $\sigma_{\Delta \gamma}$ does not equal zero, it will generally be much smaller than the standard deviation of the short-term interest rate $\sigma_{\Delta r}$, so that the ratio of central bank reserves to total bank deposits $\gamma$ receives more weight than the short-term interest rate $r$.

Third, the index of Von Hagen and Ho (2007) is driven by the most stable component. To avoid this problem, we change the weighting scheme and propose a Modified Monetary Pressure Index (MMPI):

$$
\begin{gathered}
M M P I_{t}=\omega_{1} \Delta \gamma_{t}+\omega_{2} \Delta r_{t}, \\
\omega_{1}=\frac{\frac{1}{\sigma(\Delta \gamma)}}{\frac{1}{\sigma(\Delta \gamma)}+\frac{1}{\sigma(\Delta r)}}, \omega_{2}=\frac{\frac{1}{\sigma(\Delta r)}}{\frac{1}{\sigma(\Delta \gamma)}+\frac{1}{\sigma(\Delta r)}} .
\end{gathered}
$$

The weights fall in the interval $(0,1]$ and add up to one. To illustrate the difference between the two indices, we provide an intuitive example. We set the value

\footnotetext{
${ }^{3}$ To examine the sensitivity of our findings, we have experimented with different lengths of the moving window to calculate the standard deviations.

${ }^{4}$ If the value of a standard deviation in a particular window is zero, we use the minimum positive value instead.
} 
of $\sigma_{\Delta \gamma}$ to 1 , while the value of $\sigma_{\Delta r}$ varies from 1 to 100 . Figure 1 shows the resulting values of the weights of MPI and MMPI. We find that the value of $\omega_{1}$ is smaller than $\frac{1}{\sigma(\Delta \gamma)}$ and $\omega_{2}$ is almost the same as $\frac{1}{\sigma(\Delta r)}$. In our sample (as discussed in the next section), the ratios of $\sigma_{\Delta r}$ to $\sigma_{\Delta \gamma}$ are in a range of $[1,50]$, so the weight of $\Delta \gamma$ in constructing MMPI is smaller than in constructing MPI. So our index is not driven by the most stable component.

[Insert Figure 1 here]

We deviate from the analysis of Von Hagen and Ho (2007) in two more ways. First, although Von Hagen and Ho (2007) consider both type I errors (i.e. the index does not signal a banking crisis when there is one according to some benchmark, missed crises from now on) and type II errors (i.e. the index signals a banking crisis when there is none according to the benchmark, false alarms from now on), we apply a quantitative method in assessing the performance of the indices more precisely.

Second, the sample of Von Hagen and Ho includes mostly countries which suffered from at least one banking crisis, while they include only few countries without banking crises. Therefore, there may be a sample selection bias and it is not clear whether the index is reliable in countries which did not experience banking crises. To avoid this bias, we include more countries with and without banking crises to investigate whether the index can identify banking crises in both types of countries. 


\section{Sample and criteria for identifying banking crises}

\subsection{Sample}

We use monthly data from the IMF's International Financial Statistics, spanning the period 1975 to 2009 , to construct money market pressure indices. Following Von Hagen and Ho (2007), total deposits consist of demand deposits, time and saving deposits and foreign liabilities of deposit money banks. Central bank reserves are defined as loans from monetary authorities. The nominal interest rate is the money market rate. If this variable is not available, we follow Von Hagen and Ho (2007) and use (successively) the Treasury bill rate, the government bond yield, the deposit rate, the lending rate, and the discount rate as substitutes. Changes in the consumer price index are used to measure inflation. In line with Von Hagen and Ho (2007), the real interest rate is defined as the nominal interest rate minus inflation.

We use five indices, namely VHH, RMPI, NMPI, RMMPI, and NMMPI. VHH, RMPI and RMMPI are based on real interests, while NMPI and NMMPI are constructed using nominal interest rates. These indices are defined in Table 1.

[Insert Table 1 here]

For illustrative purposes, we first zoom in on the results for a subsample of 10 countries which includes three industrial economies (Japan, Korea, and the United States), and seven developing and emerging economies (Argentina, Brazil, Indonesia, Malaysia, Mexico, Philippines, and Turkey). These 10 countries have experienced 
banking crises during the last three decades.

Table 2 presents descriptive statistics of the five indices in these countries. The means and the standard deviations of RMPI and NMPI are much larger than those of RMMPI and NMMPI. The weights as used in Equation (2) are less than 1 while in Equation (1) they can be larger than 1, so that indices based on Equation (1) can become bigger. The average of VHH is mostly somewhere between the averages of MPI and MMPI.

[Insert Table 2 here]

Because VHH is different from the other four indices, Figure 2 shows only the other four indices for selected countries. The first graph for each country shows RMPI and NMPI, and the second one presents RMMPI and NMMPI. As these figures show, RMPI and NMPI are close to each other in Argentina and Brazil, while RMMPI and NMMPI are also very similar for these countries. In contrast, the indices differ for the other countries, and sometimes quite substantially. Specifically, compared to the indices based on nominal interest rates, those based on real interest rates often show a downward trend. Furthermore, it turns out that in some countries the signs of RMMPI and NMMPI are opposite. This difference is due to the effect of inflation. For instance, both inflation and the short-term interest rate were high in Indonesia in 1997, and the indices based on the nominal interest indicate a banking crisis, while those based on the real interest rate do not. According to Laeven and Valencia (2010), Indonesia 
experienced a banking crisis in 1997.

[Insert Figure 2 here]

\subsection{Assessing crisis signals}

We assess the performance of the indices as follows. First, we use the Laeven and Valencia (2010) database as the benchmark when evaluating the results of the five indices. Due to data availability, the sample used for comparison purposes includes 136 countries with 75 banking crises. Column (2) in Appendix 1 lists all countries in our sample and their banking crises according to Laeven and Valencia (2010). Our sample includes 21 industrial economies and 115 developing economies having 11 and 64 banking crises, respectively. In addition, there are 11 industrial and 66 developing economies without a banking crisis.

Second, following Von Hagen and Ho (2007) there is a crisis if (i) the index exceeds the 98.5 percentile of the sample distribution for the country under consideration and (ii) the index increases by at least 5\% compared to the previous period.

Third, we adopt Von Hagen and Ho (2007)'s rule to decide whether a signal identifies a banking crisis correctly. If the signal indicates a banking crisis at most two years prior to the start of the crisis according to the benchmark or if the signal indicates a banking crisis at most one year later than the benchmark, this signal is considered to 
be correct. ${ }^{5}$ If the index does not signal a banking crisis when there is one according to the benchmark, it is labeled as a missed crisis. If the index signals a banking crisis when there is none according to the benchmark, then it is labeled as a false alarm (see Table $3)$.

[Insert Table 3 here]

Finally, we consider type I errors (missed crises) and type II errors (false alarms). The frequency of missed crises is defined as the number of crises listed in the benchmark that are not signaled by the index compared to the total number of crises listed in the benchmark, while the frequency of false alarms is defined as the number of crises signaled by the index which are not listed in the benchmark compared to the total number of crises signaled by the index.

\section{Results}

\subsection{Comparison of five indices}

We first compare the five indices. Table 4 zooms in on missed crises and false alarms. The indices based on nominal interest rates have fewer missed crises than those based on real interest rates. Among the five indices, NMMPI has the lowest frequency of missed crises and false alarms, so that we prefer this index to the others. ${ }^{6}$ Moreover,

\footnotetext{
${ }^{5}$ In the sensitivity analysis we also employ a window of $(\mathrm{T}-2, \mathrm{~T}+2)$ where $\mathrm{T}$ is the crisis period according to the benchmark.

${ }^{6}$ If we follow Von Hagen and Ho (2007) and use the standard deviations of the whole period to construct NMMPI, the results show that the index identifies one more correct crises, but 12 wrong crises according to the benchmark. If we use the crises database of Reinhart and Rogoff (2010) as an alternative
} 
VHH performs worse than the other indices.

[Insert Table 4 here]

All indices have very high ratios of false alarms. However, these signals may not be all wrong. First, the benchmark of Laeven and Valencia (2010) may not identify all banking crises. Indeed, 24 crises 'wrongly' identified by NMMPI are crises identified by Reinhart and Rogoff (2009). And another 20 'false alarms' are in line with the crises database of Caprio and Klingebiel (1996) (see Appendix 2 for further details).

Second, many 'false alarms' identified by NMMPI may indicate events which are not severe enough to be identified as banking crisis by our benchmark or other crises databases. For example, even though in Algeria 4 out of 17 banks failed in 2005 our benchmark does not identify this as a systemic crisis. Likewise, in many other cases there are severe economic problems, such as currency devaluations or economic downturns, which can all lead to periods with high stress in the banking system even though our benchmark does not consider this stress as sufficient reason to consider the period as a banking crisis. Appendix 3 provides further details of these cases. In our view, most of the 'false alarms' indicate crises which are missed by our benchmark, a crisis not severe enough to be considered as systemic by our benchmark, or reflects stress in the banking sector.

Since RMMPI performs slightly better than VHH and RMPI, we select RMMPI

benchmark, the index identifies the same number of correct crises, but 10 more wrong crises. As a result, we conclude that NMMPI constructed with rolling standard deviations performs better than that based on standard deviations measured over the entire sample period. 
for a more detailed comparison with NMMPI. It turns out that 45 crises correctly identified by NMMPI coincide with the benchmark, six have a 2-year lead, five have a 1-year lead, and four have a 1-year lag. RMMPI identifies 39 crises that coincide with crises identified by the benchmark, three have a 2-year lead, one has a 1-year lead, and four have a 1-year lag.

\subsection{Weighting missed crises and false alarms}

In evaluating indices, one needs to weight missed crises and false alarms. Inspired by Demirgüç-Kunt and Detragiache (2000), we use a loss function to calculate the combined costs of both types of errors and to evaluate the performance of RMMPI and NMMPI. $^{7}$

First, we describe how to construct a loss function for NMMPI. Let $H$ and $w$ be the values of the threshold, i.e. the $98.5 \%$ percentile set by Von Hagen and Ho, and weights chosen by the decision-maker, respectively. Here, $w=\left[w_{1}, w_{2}\right], w_{1}$ and $w_{2}$ are the weights of the two components to construct NMMPI in Equation (2), respectively, where we assume that $w_{1}+w_{2}=1$. If the value of the index exceeds $H$, and its growth rate is larger than $5 \%$, the index will issue a warning signal. Let $p(H, w)$ be the probability that the index issues a warning signal, and $a(H, w)$ be the probability of a missed crisis. Also, let $c_{1}$ be the cost of taking preventive actions when there is a warning signal, and let $c_{2}$ be the cost of a banking crisis if it is not predicted. Then, a simple expected loss

\footnotetext{
${ }^{7}$ An alternative way to introduce the trade-off between missed crises and false alarms is the receiver operating characteristic (ROC) as recently used in business cycle analysis (see Berger and Jorda, 2011).
} 
function can be constructed as follows:

$$
L(H, w)=p(H, w) c_{1}+a(H, w) c_{2} .
$$

In addition, let $b(H, w)$ be the probability of a false alarm, and let $P_{0}$ denote the (unconditional) probability of a banking crisis. Then, equation (3) can be rewritten as

$$
\begin{aligned}
L(H, w) & =c_{1}\left[(1-a(H, w)) p_{0}+b(H, w)\left(1-p_{0}\right)\right]+c_{2} a(H, w) p_{0} \\
& =p_{0} c_{1}\left[1+\left(\frac{c_{2}-c_{1}}{c_{1}}\right) a(H, w)+\left(\frac{1-p_{0}}{p_{0}}\right) b(H, w)\right] .
\end{aligned}
$$

It follows that that the larger $c_{2}$ is relative to $c_{1}$, missed crises are considered more important than false alarms (and vice versa).

To estimate the values of the parameters, we can use in-sample frequencies. Specifically, we take $P_{0}$ to be equal to the frequency of banking crises in the whole sample, namely 0.077. $a(H, w)$ and $b(H, w)$ can be obtained when the thresholds and weights are determined. For example, if we set $\mathrm{T}=98.5$, and $\mathrm{w}=[0.5,0.5]$, then $a(0.985,[0.5,0.5])$ is the associated probability of missed crises. Similarly, $b(0.985,[0.5,0.5])$ is the probability of false alarms.

In our analysis we let the value of $H$ range between $90 \%$ and $99 \%$ (with steps of $0.2 \%)$ to examine which value of the threshold gives the best performance of the indices. $^{8}$ Likewise, we set $c_{1}$ equal to 1 and let $\left(c_{2}-c_{1}\right)$ vary from 5 to 50 in steps of 5 .

Table 5 shows the loss for RMMPI and NMMPI in different scenarios. The table shows that the loss of RMMPI is larger than NMMPI in almost all cases, except in the case that $\left(c_{2}-c_{1}\right)$ equals 5 and 10. In addition, the loss of RMMPI increases faster than that of NMMPI when the value of $\left(c_{2}-c_{1}\right)$ varies from 5 to 50 . We therefore conclude

\footnotetext{
${ }^{8}$ Changing the second condition, i.e. the index shows an increase compared to the previous period of at least $5 \%$, has little impact on the empirical results. Results available on request.
} 
that NMMPI has a smaller loss than RMMPI and this result is robust for increasing values of $\left(c_{2}-c_{1}\right)$.

[Insert Table 5 here]

\section{Sensitivity analysis}

In this section we compare the performance of RMMPI and NMMPI for different samples of countries, sample periods, window lengths, and benchmarks. ${ }^{9}$

We first compare the performance of the two indices for different subsamples of countries. Table 6 shows the results of identifying banking crises in industrial economies and developing economies. According to the benchmark, there were 11 and 64 banking crises in industrial economies and developing economies, respectively. In industrial economies, both RMMPI and NMMPI can signal 8 out of 11 banking crises, while the frequency of false alarms of NMMPI is larger than that of RMMPI. Therefore, RMMPI performs better than NMMPI in industrial countries. In developing economies, NMMPI signals crises more accurately with fewer missed crises and false alarms than RMMPI.

[Insert Table 6 here]

To investigate the performance of our indices over time, we divide our sample

\footnotetext{
${ }^{9}$ We have done the sensitivity analysis using all indices. The results (available on request) show that RMMPI and NMMPI perform better than the other indices, so we do not show the results for the other indices.
} 
period into three sub-periods: 1970-1989, 1990-1999, and 2000-2009. Table 7 shows that the frequency of missed crises and false alarms of NMMPI is lower than that of RMMPI in all three sub-periods.

[Insert Table 7 here]

Because the weights used in constructing the indices are based on the standard deviations of a certain time window, empirical results may differ if we use different window lengths. So, we compare the four indices over different time windows. In line with Von Hagen and Ho (2007), we choose windows of 12 months, 18 months, 30 months, and 36 months. ${ }^{10}$ According to the results (available on request), NMMPI has the lowest frequency of missed crises and false alarms in all four cases.

As outlined in section 4, we have followed Von Hagen and Ho's (2007) rule to determine whether a signal correctly identifies a banking crisis, i.e. if the signal is in the window of $(\mathrm{T}-2, \mathrm{~T}+1)$ where $\mathrm{T}$ is the crisis period according to the benchmark it is considered as a correct signal. We have checked how sensitive our results are for this choice. It turns out that slightly enlarging the window to $(\mathrm{T}-2, \mathrm{~T}+2)$ hardly change the results. For illustrative purposes, Table 8 shows the outcomes for NMMPI.

[Insert Table 8 here]

\footnotetext{
${ }^{10}$ If the length of time window is too long, observations will be lost and the signal accuracy will be lower.
} 
Finally, we check whether our results depend on the benchmark chosen. As an alternative benchmark, we use the banking crises listed by Reinhart and Rogoff (2009). According to the new benchmark, our sample includes 69 banking crises from 1977 to 2009.

As Table 9 shows, NMMPI still has the lowest frequency of missed crises and false alarms, in line with our previous findings. Particularly, NMMPI2 with a time window of 24 months signals banking crises more accurately than the other indices. ${ }^{11}$

[Insert Table 9 here]

\section{Conclusion}

The identification of banking crises is crucial for further research on banking crises.

Different from the events methods, Von Hagen and Ho (2007) proposed an index of money market pressure to identify banking crises. We modify this index and apply it to a large set of countries. The main change is that in our modified index nominal interest rates are used instead of real interest rates as the former better capture money market stress, notably in developing countries. To avoid sample selection bias, our sample includes not only countries that suffered from one or more banking crises but also includes without banking crises. Our sample consists of 136 countries, including 22 industrial economies and 114 developing economies. We employ the database of banking crises in Laeven and Valencia (2010) as benchmark.

\footnotetext{
${ }^{11}$ If we compare the signals according to the Von Hagen and Ho (2007) index using the benchmark of Reinhart and Rogoff (2009), the results show that VHH can identify 42 crisis correctly and 183 wrongly. So NMMPI performs better than VHH.
} 
Our findings suggest that our preferred index outperforms the index of Von Hagen and Ho (2007). The crises indentified by our index are more in line with the benchmark of Laeven and Valencia (2010), while the index also gives fewer false alarms. This conclusion is robust when we use different groups of countries, different periods and different time windows.

We also find that money market pressure indexes, be it the original index of Von Hagen and Ho (2007) or our modified index, suggest many more banking crises than those included in the database of Laeven and Valencia (2010). We argue that most of the 'false alarms' indicate crises which are missed by our benchmark, a crisis not severe enough to be considered as systemic by our benchmark, or reflects stress in the banking sector.

\section{Acknowledgments}

This research is supported by National Natural Science Foundation of China (NSFC Grant Numbers: 70933003, 71273257). The views expressed do not necessarily reflect those of De Nederlandsche Bank.

\section{References}

Berge, T.J., Jorda, O. 2011. Evaluating the classification of economic activity into recessions and expansions American Economic Journal: Macroeconomics, 3, 246-277. Bordo, M.D., Eichengreen, B., Klingebiel, D., Martinez-Peria, M.S. 2001. Is the crisis problem growing more severe? Economic Policy 16 (32), 51-82. 
Boyd, J., De Nicolo, Loukoianova, E. 2009. Banking crises and crisis dating: Theory and evidence. IMF Working Paper 09/141.

Caprio, G., Klingebiel, D. 1996. Bank insolvencies: Cross-country experience. World Bank Policy Research Working Paper 1620.

Davis, E.P., Karima, D. (2008a). Comparing early warning systems for banking crises. Journal of Financial Stability 4 (2), 89-120.

Davis, E.P., Karima, D. (2008b). Could early warning systems have helped to predict the subprime crisis? National Institute Economic Review 206 (1), 25-37.

Demirgüç-Kunt, A., Detragiache, E. 1998. The determinants of banking crises in developed and developing countries. IMF Staff Papers 45 (1), 81-109.

Demirgüç-Kunt, A., Detragiache, E. 2000. Monitoring banking sector fragility: a multivariate logit approach. World Bank Economic Review 14 (2), 287-307.

Demirgüç-Kunt, A., Detragiache, E. 2002. Does deposit insurance increase banking sector fragility? Journal of Monetary Economics 49 (7), 1373-1406.

Demirgüç-Kunt, A., Detragiache, E. 2005. Cross-country empirical studies of systemic bank distress: A survey. IMF Working Paper 05/96.

Duttagupta, R., Cashin, P. 2008. The anatomy of banking crises. IMF Working Paper 08/93.

Eichengreen, B., Rose, A.K., Wyplosz, C. 1996a. Speculative attacks on pegged exchange rates: An empirical exploration with special reference to the European Monetary System. In: The New Transatlantic Economy, Canzoneri, M.B., Masson, P.R., Grilli, V.U. (eds.), pp. 191-228. Cambridge, Cambridge University Press. 
Eichengreen, B., Rose, A.K., Wyplosz, C. 1996b. Contagious currency crises: First tests. Scandinavian Journal of Economics 98(4), 463-84.

Frydl, E. 1999. The length and cost of banking crises. IMF Working Paper 99/30.

Furceria, D., Mourouganeb, A. 2012. The effect of financial crises on potential output: New empirical evidence from OECD countries. Journal of Macroeconomics 34 (3), $822-832$.

Hutchinson, M., Noy, I. 2005. How bad are the twins? Output costs of currency and banking crises. Journal of Money, Credit and Banking 37 (4), 725-752.

IMF. 1998. World Economic Outlook. Chapter IV: Financial crises: Characteristics and indicators of vulnerability. Washington DC, IMF.

Kaminsky, G.L., Reinhart, C.M. 1999. The twin crises: The causes of banking and balance-of-payments problems. American Economic Review 89 (3), 473-500.

Laeven, L., Valencia, F.V. 2008. System banking crises: A new database. IMF Working Paper 08/224.

Laeven, L., Valencia, F.V. 2010. Resolution of banking crises: The good, the bad, and the ugly. IMF Working Paper 10/146.

Laeven, L., Valencia, F.V. 2013. Systemic banking crisis database: An update. IMF Economic Review, 61, 225-270.

Lestano, Jacobs, J.P.A.M. 2007. Dating currency crises with ad hoc and extreme value based thresholds: East Asia 1970-2002. International Journal of Finance and Economics 12 (4), 371-388.

Reinhart, C.M., Rogoff, K. 2009. This Time is Different: Eight Centuries of Financial 
Folly. Princeton, Princeton University Press.

Von Hagen, J., Ho, T. 2007. Money market pressure and the determinants of banking crises. Journal of Money, Credit and Banking 39 (5), 1037-1066. 
Appendix 1. Summary of crises identified by different indicators

\begin{tabular}{|c|c|c|c|c|}
\hline Country & $\begin{array}{c}(1) \\
\mathrm{L} \& \mathrm{~V}(2010)\end{array}$ & $\begin{array}{c}(2) \\
\text { NMMPI }\end{array}$ & $\begin{array}{c}\text { (3) } \\
\text { VHH (2007) }\end{array}$ & $\begin{array}{c}(4) \\
\text { VHH replicated in this paper }\end{array}$ \\
\hline Albania & No & 1997-1998 & & 1997 \\
\hline Algeria & No & $\begin{array}{l}1998 \\
2005\end{array}$ & & 1998-1999 \\
\hline Angola & No & 1999-2001 & & $\begin{array}{l}1999 \\
2009\end{array}$ \\
\hline Antigua and Barbuda & No & $\begin{array}{l}2001 \\
2009\end{array}$ & & $\begin{array}{l}2001 \\
2009\end{array}$ \\
\hline Argentina & $\begin{array}{l}1980-1982 \\
1989-1991 \\
1995 \\
2001-2003\end{array}$ & $\begin{array}{l}1983 \\
1989-1990\end{array}$ & 1989-1990 & $\begin{array}{l}1982 \\
1989-1991\end{array}$ \\
\hline Armenia & No & 1999 & & $\begin{array}{l}1999 \\
2008\end{array}$ \\
\hline Aruba & No & 1995-1999 & & $\begin{array}{l}1988 \\
1995-1997\end{array}$ \\
\hline Austria & No & $\begin{array}{l}1977-1981 \\
1988\end{array}$ & & $1977-1981$ \\
\hline Azerbaijan & No & 2009 & & 2002-2006 \\
\hline Bahamas, The & No & $\begin{array}{l}1983-1987 \\
1990\end{array}$ & & $\begin{array}{l}1978-1980 \\
1984-1988\end{array}$ \\
\hline Bangladesh & No & $\begin{array}{l}1996 \\
2006-2008\end{array}$ & & $\begin{array}{l}1996 \\
2008\end{array}$ \\
\hline Barbados & No & $\begin{array}{l}1981-1983 \\
1989-1992\end{array}$ & & $\begin{array}{l}1981-1983 \\
1989-1991\end{array}$ \\
\hline Belarus & No & 1998-2000 & & $1997-1998$ \\
\hline Benin & No & $2007-2008$ & & 2008 \\
\hline Bolivia & No & $2002-2003$ & & 2002-2004 \\
\hline Botswana & No & 2004 & & 2005 \\
\hline Brazil & $\begin{array}{l}\text { 1990-1994 } \\
1994-1998\end{array}$ & 1994-1998 & 1989 & $\begin{array}{l}1990 \\
1997 \\
2001\end{array}$ \\
\hline $\begin{array}{l}\text { Bulgaria } \\
\text { Burkina Faso }\end{array}$ & $\begin{array}{l}1996-1997 \\
1990-1994\end{array}$ & $\begin{array}{l}1996 \\
1979-1981 \\
1992 \\
2007\end{array}$ & & $\begin{array}{l}1995-1996 \\
1979-1981\end{array}$ \\
\hline
\end{tabular}




\begin{tabular}{|c|c|c|c|c|}
\hline Country & $\begin{array}{c}(1) \\
L \& V(2010)\end{array}$ & $\begin{array}{c}(2) \\
\text { NMMPI }\end{array}$ & \begin{tabular}{|c|}
$(3)$ \\
VHH (2007) \\
\end{tabular} & $\begin{array}{c}(4) \\
\text { VHH replicated in this paper }\end{array}$ \\
\hline Burundi & 1994-1998 & $\begin{array}{l}1995-1996 \\
2001\end{array}$ & & $\begin{array}{l}1991 \\
1995-1996\end{array}$ \\
\hline $\begin{array}{l}\text { Cambodia } \\
\text { Cameroon }\end{array}$ & No & 2003 & & $\begin{array}{l}1999-2003 \\
1984\end{array}$ \\
\hline & $\begin{array}{l}1987-1991 \\
1995-1997\end{array}$ & $\begin{array}{l}1988-1990 \\
1994-1997\end{array}$ & & $1987-1990$ \\
\hline Canada & No & \begin{tabular}{|c}
$1985-1986$ \\
$1991-1992$
\end{tabular} & & $\begin{array}{l}1979-1980 \\
1985-1986\end{array}$ \\
\hline $\begin{array}{l}\text { Cape Verde } \\
\text { Central African Republic }\end{array}$ & No & $2000-2003$ & & $\begin{array}{l}2000-2003 \\
1983-1985\end{array}$ \\
\hline & 1995-1996 & $\begin{array}{l}1994-1996 \\
1998\end{array}$ & & $\begin{array}{l}1994 \\
1999\end{array}$ \\
\hline Chad & 1992-1996 & 1990-1994 & & $\begin{array}{l}1988-1989 \\
1997 \\
1998\end{array}$ \\
\hline Chile & No & 2004 & 1984 & 2004 \\
\hline China, P.R.: Macao & No & 1997-2000 & & $\begin{array}{l}2000-2004 \\
2009\end{array}$ \\
\hline Colombia & $1998-2000$ & 1999 & & $2005-2007$ \\
\hline Congo, Republic of & 1992-1994 & 1994-1995 & & $\begin{array}{l}1995 \\
1998-2000\end{array}$ \\
\hline Costa Rica & $\begin{array}{l}1987-1991 \\
1994-1995\end{array}$ & $\begin{array}{l}1986-1990 \\
1994-1995\end{array}$ & & $\begin{array}{l}1985-1986 \\
1994 \\
1997 \\
2003\end{array}$ \\
\hline Cote d'Ivoire & No & $\begin{array}{l}1979-1982 \\
1992\end{array}$ & 1980 & 1981-1985 \\
\hline Croatia & 1998-1999 & $2008-2009$ & 1995 & $\begin{array}{l}1997-1998 \\
2001 \\
2009\end{array}$ \\
\hline Cyprus & No & $\begin{array}{l}1998 \\
2006\end{array}$ & & $2004-2006$ \\
\hline Czech Republic & $1996-2000$ & $\begin{array}{l}1997-1998 \\
2005\end{array}$ & & 2005-2008 \\
\hline
\end{tabular}




\begin{tabular}{|c|c|c|c|c|}
\hline Country & $\begin{array}{c}(1) \\
L \& V(2010)\end{array}$ & $\begin{array}{c}(2) \\
\text { NMMPI }\end{array}$ & \begin{tabular}{|c|}
$(3)$ \\
VHH (2007)
\end{tabular} & $\begin{array}{c}\text { (4) } \\
\text { VHH replicated in this paper }\end{array}$ \\
\hline \multirow[t]{4}{*}{ Denmark } & & $1978-1982$ & 1982 & \\
\hline & & 1993 & 1993 & 1993-1995 \\
\hline & & & & 2001-2004 \\
\hline & 2008-2009 & & & 2008 \\
\hline Djibouti & No & 2008 & & 2008-2009 \\
\hline \multirow[t]{3}{*}{ Dominica } & & $1988-1993$ & & 1993 \\
\hline & & 2001 & & $1999-2000$ \\
\hline & 2003-2004 & & & 2005 \\
\hline \multirow[t]{2}{*}{ Dominican Republic } & No & $2003-2004$ & & 2003 \\
\hline & & & & 2009 \\
\hline \multirow[t]{3}{*}{ Ecuador } & $1982-1986$ & & & \\
\hline & & 1992-1993 & & 1992 \\
\hline & $1998-2002$ & 1998 & & 1998-1999 \\
\hline Egypt & No & $2004-2008$ & & 2007 \\
\hline El Salvador & No & 1999 & & 1999 \\
\hline \multirow[t]{2}{*}{ Equatorial Guinea } & No & $1990-1994$ & & 1989-1991 \\
\hline & & 1996 & & \\
\hline \multirow[t]{2}{*}{ Estonia } & No & 1997 & & 1996 \\
\hline & & & & $2005-2006$ \\
\hline \multirow[t]{2}{*}{ Fiji } & No & 1994-1996 & & 1994-1997 \\
\hline & & 2000 & & \\
\hline \multirow[t]{3}{*}{ Finland } & & 1986 & 1989 & \\
\hline & 1991-1995 & 1991-1992 & & 1991-1995 \\
\hline & & & & 1997 \\
\hline \multirow[t]{2}{*}{ France } & No & $1979-1982$ & & 1978-1979 \\
\hline & & 1992 & & $1992-1993$ \\
\hline \multirow[t]{2}{*}{ Gabon } & No & 1994-1998 & & $1992-1995$ \\
\hline & & & & 2002 \\
\hline \multirow[t]{3}{*}{ Gambia, The } & No & $1987-1990$ & & 1988 \\
\hline & & 2002 & & \\
\hline & & & & 2008 \\
\hline Georgia & No & 2003-2006 & & 2004-2006 \\
\hline \multirow[t]{3}{*}{ Greece } & No & & 1984 & \\
\hline & & 1991 & & \\
\hline & & 1997 & & $1997-2000$ \\
\hline \multirow[t]{3}{*}{ Grenada } & No & 1987-1989 & & 1988-1989 \\
\hline & & 2001 & & \\
\hline & & & & 2008 \\
\hline Guatemala & No & 2001 & & 2001 \\
\hline
\end{tabular}




\begin{tabular}{|c|c|c|c|c|}
\hline Country & $\begin{array}{c}(1) \\
\mathrm{L} \& \mathrm{~V}(2010) \\
\end{array}$ & $\begin{array}{c}(2) \\
\text { NMMPI }\end{array}$ & \begin{tabular}{|c|}
$(3)$ \\
VHH (2007) \\
\end{tabular} & $\begin{array}{c}(4) \\
\text { VHH replicated in this paper }\end{array}$ \\
\hline Guinea-Bissau & 1995-1998 & $\begin{array}{l}1992 \\
2008\end{array}$ & & $\begin{array}{l}1993 \\
2008\end{array}$ \\
\hline Haiti & 1994-1998 & $2000-2003$ & & $2000-2003$ \\
\hline Honduras & No & 1994-1995 & & 1987-1991 \\
\hline Hungary & $\begin{array}{l}1991-1995 \\
2008-2009\end{array}$ & $\begin{array}{l}1993 \\
2008\end{array}$ & & $\begin{array}{l}2001 \\
2006-2008\end{array}$ \\
\hline $\begin{array}{l}\text { Iceland } \\
\text { Indonesia }\end{array}$ & No & 2001-2002 & 1985 & 2002-2005 \\
\hline & $1997-2001$ & $1997-1998$ & 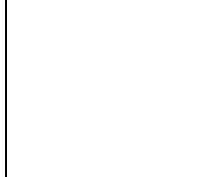 & $\begin{array}{l}1990-1993 \\
1998 \\
2005\end{array}$ \\
\hline Israel & No & 1988-1991 & & 1989-1993 \\
\hline Italy & No & $\begin{array}{l}1979 \\
1992-1995\end{array}$ & 1992 & 1998 \\
\hline Jamaica & No & $\begin{array}{l}2002 \\
2009\end{array}$ & & $\begin{array}{l}2000 \\
2009\end{array}$ \\
\hline Japan & 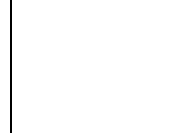 & $1979-1980$ & $\begin{array}{l}1980 \\
1985\end{array}$ & 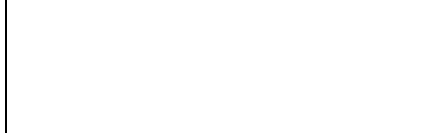 \\
\hline & $1997-2001$ & $\begin{array}{l}1995 \\
2006\end{array}$ & 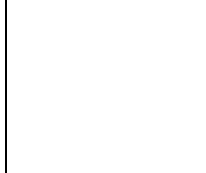 & $\begin{array}{l}1995 \\
2003-2004\end{array}$ \\
\hline $\begin{array}{l}\text { Jordan } \\
\text { Kazakhstan }\end{array}$ & No & $\begin{array}{l}2004-2006 \\
1999\end{array}$ & & 2004-2005 \\
\hline & $2008-2009$ & 2007 & & 2003-2004 \\
\hline Kenya & 1985 & 1982 & & 1978 \\
\hline & 1992-1994 & $\begin{array}{l}1993-1994 \\
2002\end{array}$ & 1993 & $\begin{array}{l}1992-1994 \\
2002-2003\end{array}$ \\
\hline Korea, Republic of & $1997-1998$ & $\begin{array}{l}1984-1988 \\
1990-1992 \\
1997\end{array}$ & & $\begin{array}{l}1984-1988 \\
1992 \\
1997\end{array}$ \\
\hline Kuwait & No & 1995-1998 & & $\begin{array}{l}1998-2000 \\
2009\end{array}$ \\
\hline Kyrgyz Republic & 1995-1999 & 1998 & & 1999-2000 \\
\hline
\end{tabular}




\begin{tabular}{|c|c|c|c|c|}
\hline Country & $\begin{array}{c}(1) \\
\mathrm{L} \& \mathrm{~V}(2010)\end{array}$ & $\begin{array}{c}(2) \\
\text { NMMPI }\end{array}$ & $\begin{array}{c}(3) \\
\text { VHH (2007) }\end{array}$ & $\begin{array}{c}(4) \\
\text { VHH replicated in this paper }\end{array}$ \\
\hline \multirow[t]{2}{*}{ Lao, P.D.R. } & No & 2001 & & 2001 \\
\hline & & & & 2009 \\
\hline \multirow[t]{3}{*}{ Latvia } & 1995-1996 & & & \\
\hline & & 2001 & & 1999-2001 \\
\hline & 2008 & 2009 & & 2008 \\
\hline Liberia & No & 2008 & & 2008 \\
\hline \multirow[t]{2}{*}{ Lithuania } & 1995-1996 & 1996 & & \\
\hline & & 1999 & & 1998-1999 \\
\hline \multirow[t]{2}{*}{ Macedonia, FYR } & No & 1996 & & \\
\hline & & 2006 & & 2006-2007 \\
\hline Madagascar & No & $2005-2008$ & & 2008 \\
\hline \multirow[t]{2}{*}{ Malawi } & No & 1992 & & 1992-1996 \\
\hline & & 2006-2008 & & 2006-2008 \\
\hline \multirow[t]{3}{*}{ Malaysia } & 1997-1999 & 1997-1998 & & 1997 \\
\hline & & & & 2001 \\
\hline & & & & 2008 \\
\hline \multirow[t]{3}{*}{ Mali } & 1987-1991 & 1992 & & \\
\hline & & & & 1996-1998 \\
\hline & & 2008 & & 2007 \\
\hline \multirow[t]{4}{*}{ Mauritius } & No & 1983 & & 1981 \\
\hline & & 1993-1994 & & 1993 \\
\hline & & 2001 & & 2001 \\
\hline & & 2008 & & 2008 \\
\hline \multirow[t]{4}{*}{ Mexico } & 1981-1985 & & & \\
\hline & 1994-1996 & 1994-1995 & & 1994 \\
\hline & & 1998-1999 & & \\
\hline & & & & 2005-2009 \\
\hline \multirow[t]{2}{*}{ Moldova } & No & 1998 & & \\
\hline & & 2006 & & 2009 \\
\hline \multirow[t]{2}{*}{ Mongolia } & & 1997-1998 & & 1998 \\
\hline & 2008-2009 & 2008 & & 2008 \\
\hline \multirow[t]{2}{*}{ Morocco } & No & 2001-2005 & & \\
\hline & & & & 2008-2009 \\
\hline Mozambique & No & $2001-2005$ & & 2001-2005 \\
\hline \multirow[t]{2}{*}{ Myanmar } & No & 1996 & & \\
\hline & & $2001-2003$ & & 2001-2003 \\
\hline Namibia & No & 2007 & & 2006 \\
\hline
\end{tabular}




\begin{tabular}{|c|c|c|c|c|}
\hline Country & $\begin{array}{c}(1) \\
\mathrm{L} \& \mathrm{~V}(2010)\end{array}$ & $\begin{array}{c}(2) \\
\text { NMMPI }\end{array}$ & $\begin{array}{c}(3) \\
\text { VHH (2007) }\end{array}$ & $\begin{array}{c}\text { (4) } \\
\text { VHH replicated in this paper }\end{array}$ \\
\hline \multirow[t]{3}{*}{ Nepal } & & & & 1985 \\
\hline & 1988 & 1989-1990 & & 1988 \\
\hline & & $2005-2008$ & & 2004-2008 \\
\hline \multirow[t]{4}{*}{ Netherlands } & No & 1978-1979 & & \\
\hline & & & 1981 & 1983-1984 \\
\hline & & 1988 & 1986 & \\
\hline & & & & 1990-1994 \\
\hline \multirow[t]{2}{*}{ Nicaragua } & 1990-1993 & 1990 & & 1990 \\
\hline & $2000-2001$ & & & \\
\hline \multirow[t]{4}{*}{ Niger } & & 1979 & & 1979 \\
\hline & 1983-1985 & 1981 & & 1987 \\
\hline & & 1992-1994 & & 1994-1998 \\
\hline & & & & 2009 \\
\hline \multirow[t]{3}{*}{ Nigeria } & & & 1989 & \\
\hline & 1991-1995 & 1994-1995 & 1996 & 1995 \\
\hline & & 1999 & & 2002 \\
\hline \multirow[t]{3}{*}{ Norway } & & 1982-1986 & & 1986-1987 \\
\hline & 1991-1993 & 1992 & & \\
\hline & & & & 2004-2006 \\
\hline Oman & No & 2004 & & 2004 \\
\hline \multirow[t]{4}{*}{ Pakistan } & No & 1981-1985 & & 1981 \\
\hline & & 1991-1992 & & \\
\hline & & $1996-2000$ & & $1997-2000$ \\
\hline & & & & 2003-2006 \\
\hline Panama & No & 2006 & & 2005 \\
\hline \multirow[t]{3}{*}{ Paraguay } & 1995 & 1997 & & 1997 \\
\hline & & & & $2005-2006$ \\
\hline & & 2009 & & \\
\hline \multirow[t]{2}{*}{ Peru } & No & 1998 & & \\
\hline & & 2008 & & $2005-2008$ \\
\hline \multirow[t]{2}{*}{ Philippines } & & 1989-1990 & & 1990 \\
\hline & 1997-2001 & 2001 & & $2000-2001$ \\
\hline \multirow[t]{3}{*}{ Poland } & 1992-1994 & 1993-1994 & & \\
\hline & & & & $1997-2002$ \\
\hline & & & & 2008 \\
\hline \multirow[t]{3}{*}{ Portugal } & No & & 1985 & \\
\hline & & 1990-1992 & 1991 & \\
\hline & & & & 1993-1994 \\
\hline
\end{tabular}




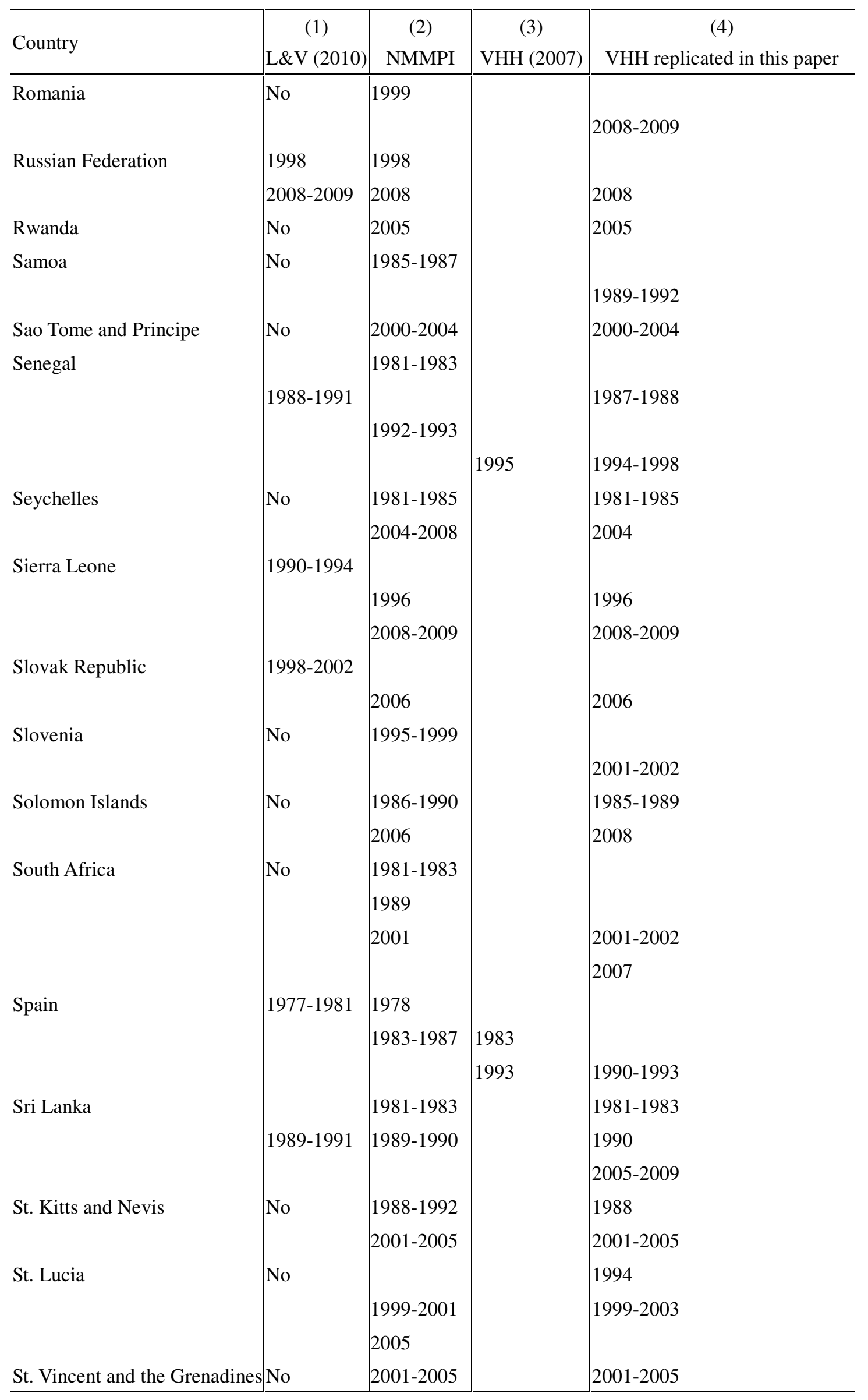




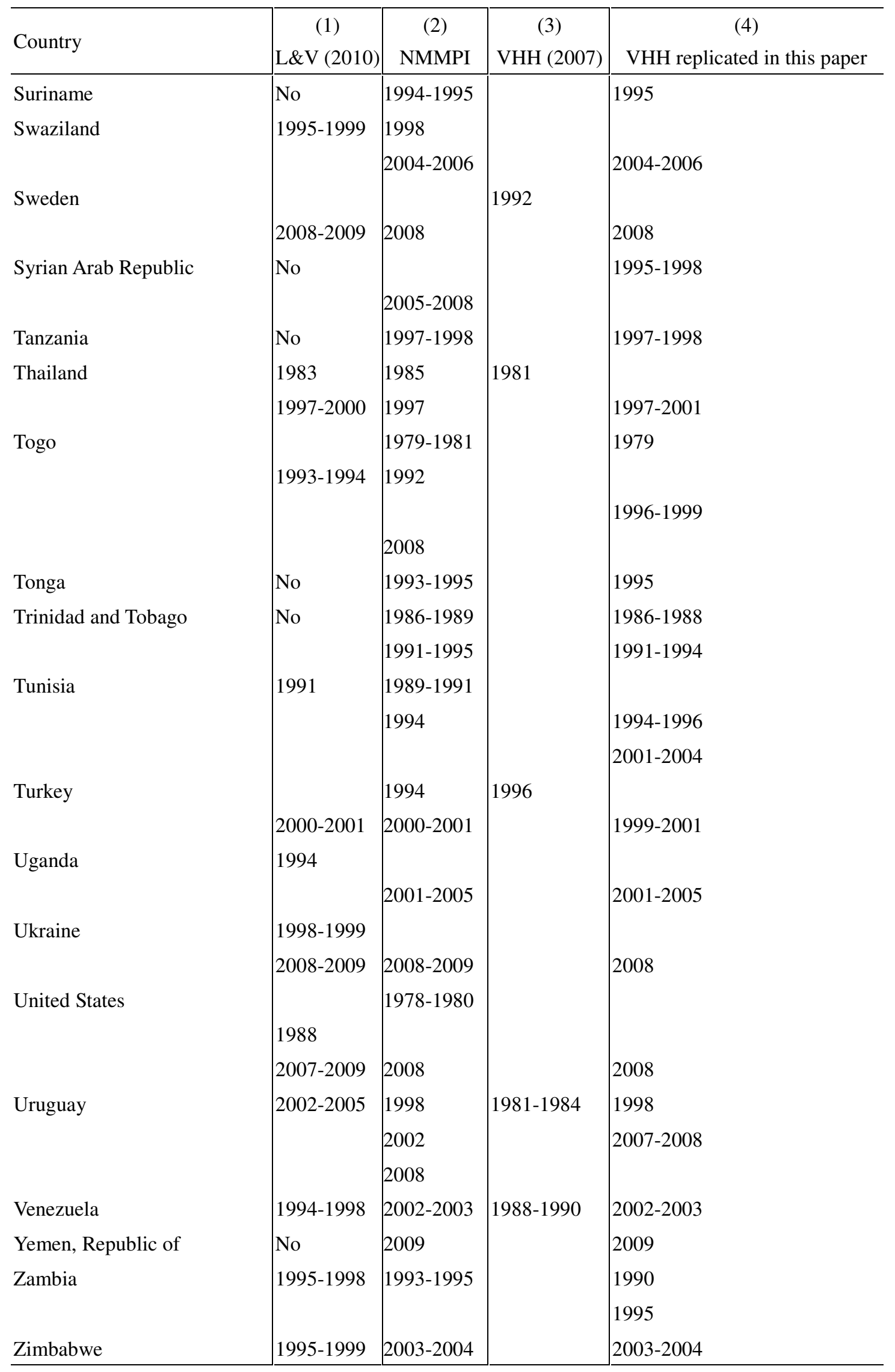

Note: This table shows banking crises according to Laeven and Valencia (2010), and signalled crises according to several pressure indexes for all countries in our sample. Column (1) shows the crises listed in Laeven and Valencia (2010), where "No" indicates that there is no crisis. Column (2) shows all crises 
identified by our preferred index, NMMPI. Column (3) shows the crises according to the index of Von Hagen and Ho (2007), while column (4) shows the crises if we apply the method of Von Hagen and Ho (2007) to our data. 
Appendix 2. Signaled crises according to NMMPI that are in line with crises according to Reinhart and Rogoff (2009) and/or Caprio and Klingebiel (1996)

\begin{tabular}{|c|c|c|}
\hline Country & Signaled crises & Crises periods in the literature \\
\hline Angola & $1999-2001$ & $1992-1998$ \\
\hline Bahamas, The & $1983-1987 ; 1990$ & Late $1980 \mathrm{~s}$ \\
\hline Belarus & 1998 & $1995-?$ \\
\hline Canada & $1985-1986$ & $1983-1985$ \\
\hline Central African Rep & 1998 & 1988-1999 \\
\hline China, P.R.: Macao & $1997-2000$ & 1992-1999 \\
\hline Cote d'Ivoire & 1992 & $1988-1991$ \\
\hline Dominican Rep & $2003-2004$ & 2003 \\
\hline Estonia & 1997 & 1998 \\
\hline France & 1992 & 1994-1995 \\
\hline Gabon & 1994-1998 & 1995-? \\
\hline Gambia, The & $1987-1990$ & $1985-1992$ \\
\hline Greece & 1991 & 1991-1995 \\
\hline Guatemala & 2001 & 2001 \\
\hline Guinea-Bissau & 1992 & 1995-? \\
\hline Italy & 1992-1995 & $1990-1995$ \\
\hline Kenya & 1982 & $1985-1989$ \\
\hline Kenya & 2002 & 1996-2002 \\
\hline Korea, Rep & 1984-1988 & 1983-1988 \\
\hline Latvia & 2001 & $1995-2002$ \\
\hline Macedonia, FYR & 1996 & 1993-1994 \\
\hline Mexico & 1998-1999 & $1994-2000$ \\
\hline Myanmar & 1996 & 1996 \\
\hline Myanmar & $2001-2003$ & 1996-? \\
\hline Nepal & 1990 & 1988 \\
\hline Niger & 1992-1994 & Late $1980 \mathrm{~s}$ \\
\hline Nigeria & 1999 & 2001-2002 \\
\hline Norway & $1982-1986$ & $1988-1993$ \\
\hline Paraguay & 1997 & $1995-2002$ \\
\hline Peru & 1998 & 1999 \\
\hline Philippines & $1989-1990$ & $1981-1987$ \\
\hline Romania & 1999 & $1990-2002$ \\
\hline Sao Tome and Principe & $2000-2004$ & 1980s-1990s \\
\hline Senegal & 1993 & 1988-1991 \\
\hline Sierra Leone & 1996 & $1990-2002$ \\
\hline Spain & $1983-1987$ & $1977-1985$ \\
\hline Tanzania & 1997-1998 & Late 1980s; 1990s \\
\hline Thailand & 1985 & $1980-1987$ \\
\hline Tunisia & 1994 & 1991-1995 \\
\hline Turkey & 1994 & 1994 \\
\hline
\end{tabular}




\begin{tabular}{lll}
\hline Country & Signaled crises & Crises periods in the literature \\
\hline Uganda & $2001-2005$ & $1994-2002$ \\
Venezuela & $2002-2003$ & $1994-2002$ \\
Zimbabwe & $2003-2004$ & $1995-2008$ \\
\hline
\end{tabular}

Note: This table summarizes the crises identified by NMMPI that are not in line with the database of Laeven and Valencia (2010), while they are in line with the crises periods as identified by Reinhart and Rogoff (2009) and Caprio and Klingebiel (1996). The second column indicates the crises periods identified by NMMPI. The third column indicates the crises periods given by Reinhart and Rogoff (2009) and/or Caprio and Klingebiel (1996). 
Appendix 3. Signals which coincide with stress

\begin{tabular}{|c|c|c|c|}
\hline Country & Signaled crises: & Events: & Source: \\
\hline Albania & $1997-1998$ & $\begin{array}{l}\text { In 1997, the Rural Commercial Bank, a state-owned bank, was } \\
\text { closed. }\end{array}$ & $\begin{array}{l}\text { http://www.bankofalbania.org/web/Brief_History_of_Banking_Supervision_in_ } \\
\text { Albania_52_2.php }\end{array}$ \\
\hline Algeria & $1998 ; 2005$ & $\begin{array}{l}\text { Public banks' losses averaged over } 4 \text { percent of GDP each year } \\
\text { from } 1991 \text { to } 2002 \text {. Financial restructuring of banks occurred in } \\
1991-94,1995-98 \text {, and } 2001 \text {. }\end{array}$ & http://www.imf.org/external/pubs/ft/scr/2004/cr04138.pdf \\
\hline Armenia & 1999 & In 2000 , RNPL reached a peak of $17.5 \%$ & http://www.financebycountry.com/Armenia/indicator-non_performing_loans/ \\
\hline Bangladesh & 1996 & $\begin{array}{l}\text { All banks had high levels of non-performing loans. In 1998, the } \\
\text { RNPL reached } 40 \% \text {. }\end{array}$ & $\begin{array}{l}\text { http://www.apu.ac.jp/rcaps/uploads/fckeditor/publications/journal/RJAPS_V29_ } \\
\text { Uddin.pdf }\end{array}$ \\
\hline Bolivia & $2002-2003$ & The average RNPL for $2001-03$ is about $17 \%$. & http://www.financebycountry.com/Bolivia/indicator-non_performing_loans/ \\
\hline Cambodia & 2003 & The average RNPL to total assets in $2002-2003$ is about $14 \%$. & http://www.acledabank.com.kh/kh/assets/pdf_zip/Conference2007_05.pdf \\
\hline Canada & $1991-1992$ & In 1991-1992, 9 financial companies collapsed. & $\begin{array}{l}\text { http://en.wikipedia.org/wiki/Canada_Deposit_Insurance_Corporation\#List_of_fi } \\
\text { nancial_collapses_since_1967 }\end{array}$ \\
\hline Chile & 2004 & Affected by the crisis in Argentina in 2002. & $\begin{array}{l}\text { http://www.eclac.cl/cgi-bin/getProd.asp?xml=/prensa/noticias/comunicados/9/10 } \\
\text { 739/P10739.xml\&xsl=/prensa/tpl-i/p6f.xsl\&base=/tpl/top-bottom.xslt }\end{array}$ \\
\hline Czech Republic & 2005 & The average RNPL in $2001-03$ is about $8.5 \%$. & $\begin{array}{l}\text { http://www.financebycountry.com/Czech-Republic/indicator-non_performing_lo } \\
\text { ans/ }\end{array}$ \\
\hline Denmark & 1993 & Crises occurred in 1987-1992 & Von Hagen and Ho (2007) \\
\hline El Salvador & 1999 & Two bank failures in 1997 and 1998. & http://www.frbatlanta.org/filelegacydocs/erq306_quispe.pdf \\
\hline
\end{tabular}




\begin{tabular}{|c|c|c|c|}
\hline Country & Signaled crises: & Events: & Source: \\
\hline Finland & 1986 & $\begin{array}{l}\text { The incompatibility of prudential regulation with the more } \\
\text { competitive environment of the late } 1980 \text { was a reason for the } \\
\text { fragility of the banks which was revealed in the Finnish banking } \\
\text { crisis of the early 1990s. }\end{array}$ & $\begin{array}{l}\text { http://www.bancaditalia.it/studiricerche/convegni/atti/Financial_Market_Regulati } \\
\text { on/sessione_a/paper_TARKKA.pdf }\end{array}$ \\
\hline Fiji & 1994-1996 & $\begin{array}{l}\text { State-owned banks failed in the } 1990 \text { s, requiring restructuring } \\
\text { and recapitalization. }\end{array}$ & $\begin{array}{l}\text { http://www.microfinance-pasifika.org/assets/newsitefiles/reports/ADB_Pacific_F } \\
\text { inancial_Sector_Review_Vol_1.pdf }\end{array}$ \\
\hline Georgia & 2003-2006 & The average RNPL for $2001-02$ is about $10.3 \%$. & http://www.financebycountry.com/Georgia/indicator-non_performing_loans/ \\
\hline Greece & 1997 & $\begin{array}{l}\text { Up to the second half of the } 1990 \text { s almost } 2 / 3 \text { of Greek banks } \\
\text { were controlled by the State and were moreover, badly run. }\end{array}$ & http://www.bis.org/review/r060907c.pdf \\
\hline Honduras & $1994-1995$ & The average RNPL for $1998-2000$ is about $11 \%$. & http://www.financebycountry.com/Honduras/indicator-non_performing_loans/ \\
\hline Iceland & 2001-2002 & $\begin{array}{l}\text { In } 2001 \text { the banking system was deregulated in Iceland. The big } \\
\text { and aggressive growth of Iceland's banks started to become } \\
\text { remarkable, because of the small economy of Iceland. }\end{array}$ & http://www.studymode.com/essays/Icelandic-Bank-System-972315.html \\
\hline Israel & $1988-1991$ & In 1986, the Sheqel's link to the U.S. Dollar was broken. & http://intl.econ.cuhk.edu.hk/exchange_rate_regime/index.php?cid=24 \\
\hline Jamaica & 2002 & $\begin{array}{l}\text { From } 1996-2002 \text {, the banking system had a negative asset } \\
\text { growth rate and the RNPL was } 12.43 \% \text {. }\end{array}$ & $\begin{array}{l}\text { http://boj.org.jm/uploads/pdf/papers_pamphlets/papers_pamphlets_An_Early_W } \\
\text { arning_Model_of_Bank_Failure_in_Jamaica__An_Information_Theoretic_Appr } \\
\text { oach.pdf }\end{array}$ \\
\hline Kazakhstan & 1999 & $\begin{array}{l}\text { Between } 1998 \text { and } 2001 \text { the number of banks decreased from } 71 \\
\text { to } 48 \text { due to bank regulation. }\end{array}$ & http://images.mofcom.gov.cn/ozs/table/kaza/banking.pdf \\
\hline Kuwait & $1995-1998$ & From 1998 to 2000 , the RNPL increase from $10.3 \%$ to $19.2 \%$. & http://www.financebycountry.com/Kuwait/indicator-non_performing_loans/ \\
\hline Macedonia, FYR & 2006 & The average RNPL for $2002-05$ is about $20 \%$. & http://www.financebycountry.com/Macedonia/indicator-non_performing_loans/ \\
\hline Moldova & 1998 & Affected by the crisis in Russia in 1998. & http://en.wikipedia.org/wiki/Economy_of_Moldova \\
\hline Mongolia & $1997-1998$ & There was a banking crisis in 1998-1999. & http://www.mongolbank.mn/eng/listfinstability.aspx?did=5 \\
\hline Morocco & $2001-2005$ & The average RNPL for $2001-03$ is about $20 \%$. & http://www.financebycountry.com/Morocco/indicator-non_performing_loans/ \\
\hline Mozambique & 2001-2005 & The average RNPL for $2001-05$ is about $17.5 \%$. & http://www.financebycountry.com/Mozambique/indicator-non_performing_loans \\
\hline
\end{tabular}




\begin{tabular}{|c|c|c|c|}
\hline Country & Signaled crises: & Events: & Source: \\
\hline Oman & 2004 & The average RNPL for $2003-04$ peaked at about $12 \%$. & http://www.financebycountry.com/Oman/indicator-non_performing_loans/ \\
\hline Pakistan & $\begin{array}{l}1991-1992 ; \\
1996-2000\end{array}$ & $\begin{array}{l}\text { The banking sector of Pakistan went through major reforms } \\
\text { since 1990; at the end of the 1990s loan default rates increased. }\end{array}$ & $\begin{array}{l}\text { http://www.ukessays.com/essays/economics/how-privatization-effects-banking-s } \\
\text { ector-of-pakistan-economics-essay.php\#ixzz2enUEcGaB }\end{array}$ \\
\hline Portugal & 1990-1992 & Crises occurred in 1986-1989. & Demirgüç-Kunt and Detragiache (2005) \\
\hline Rwanda & 2005 & The average RNPL for $2001-05$ is about $45 \%$. & http://www.financebycountry.com/Rwanda/indicator-non_performing_loans/ \\
\hline Slovenia & 1995-1999 & $\begin{array}{l}\text { The only bankruptcy in the banking system in Slovenia took } \\
\text { place in the year } 1996 .\end{array}$ & http://www.oecd.org/finance/financial-markets/49497940.pdf \\
\hline South Africa & $1981-1983$ & $\begin{array}{l}\text { Financial crises occurred due to default of foreign banks in } \\
1985 .\end{array}$ & Demirgüç-Kunt and Detragiache (2005) \\
\hline South Africa & 2001 & Three banks failed in 2001-2002. & $\begin{array}{l}\text { http://www.resbank.co.za/Publications/Reports/Documents/Annual\%20Report\% } \\
\text { 202001.pdf }\end{array}$ \\
\hline Suriname & 1994-1995 & In 1994 the inflation rate was over $400 \%$. & http://www.encyclopedia.com/topic/Suriname.aspx \\
\hline $\begin{array}{ll}\text { Syrian } & \text { Arab } \\
\text { Republic } & \end{array}$ & 2005-2008 & $\begin{array}{l}\text { In } 2004-2005 \text {, the fast-paced credit expansion is likely to have } \\
\text { weakened the quality of banks' loan portfolios — given weak } \\
\text { risk management practices_-and made banks run into liquidity } \\
\text { problems. }\end{array}$ & http://www.bi-me.com/main.php?id=5344\&t=1\&c=6\&cg=2\&mset $=$ \\
\hline Tonga & 1993-1995 & One foreign-owned bank was in trouble. & $\begin{array}{l}\text { http://www.microfinance-pasifika.org/assets/newsitefiles/reports/ADB_Pacific_F } \\
\text { inancial_Sector_Review_Vol_1.pdf }\end{array}$ \\
\hline United States & $1978-1980$ & Crises occurred in 1980-1992. & Von Hagen and Ho (2007) \\
\hline Uruguay & 2002-2005 & Affected by the crisis in Argentina at 2002. & $\begin{array}{l}\text { http://www.eclac.cl/cgi-bin/getProd.asp?xml=/prensa/noticias/comunicados/9/10 } \\
\text { 739/P10739.xml\&xsl=/prensa/tpl-i/p6f.xsl\&base=/tpl/top-bottom.xslt }\end{array}$ \\
\hline
\end{tabular}

Note: This table indicates important events during the periods identified by NMMPI. The second column lists the crises periods, the third column lists the important events, and the last column lists the resources from where we collect the information. "RNPL" denotes the ratio of non-performing loans to total assets. 
Table 1. Definition of indices used

\begin{tabular}{|c|c|}
\hline Index & Definition \\
\hline VHH & MPI proposed by Von Hagen and Ho (2007) \\
\hline RMPI & $\begin{array}{l}\text { MPI constructed using real interest rates and 24-months moving window for standard } \\
\text { deviation }\end{array}$ \\
\hline NMPI & $\begin{array}{l}\text { MPI constructed using nominal interest rates and 24-months moving window for } \\
\text { standard deviation }\end{array}$ \\
\hline RMMPI & $\begin{array}{l}\text { MMPI (equation 2) constructed by using real interest rates and 24-months moving } \\
\text { window for standard deviation }\end{array}$ \\
\hline NMMPI & $\begin{array}{l}\text { MMPI (equation 2) constructed by using nominal interest rates and 24-months moving } \\
\text { window for standard deviation }\end{array}$ \\
\hline
\end{tabular}

Note: This table shows the definitions of five indices used in the empirical tests. 
Table 2. Summary of money market pressure indices for 10 countries

\begin{tabular}{|c|c|c|c|c|c|c|c|c|}
\hline Country & Index & Mean & $\operatorname{Max}$ & Min & Median & S.D & $\mathrm{N}$ & Number of crises \\
\hline \multirow[t]{5}{*}{ Argentina } & VHH & -0.062 & 8.628 & -11.26 & -0.013 & 1.423 & 345 & 4 \\
\hline & RMPI & 6.355 & 215.571 & -16.03 & -0.166 & 115.874 & 345 & \\
\hline & NMPI & 12.524 & 419.15 & -16.053 & -0.107 & 225.876 & 345 & \\
\hline & RMMPI & 0.08 & 27.864 & -0.368 & -0.001 & 1.501 & 345 & \\
\hline & NMMPI & 0.166 & 54.305 & -0.528 & -0.001 & 2.925 & 345 & \\
\hline \multirow[t]{5}{*}{ Brazil } & VHH & -0.051 & 7.866 & -7.622 & -0.005 & 1.409 & 230 & 2 \\
\hline & RMPI & -0.204 & 11.785 & -21.236 & -0.224 & 2.235 & 230 & \\
\hline & NMPI & 0.034 & 15.297 & -16.027 & -0.122 & 2.232 & 230 & \\
\hline & RMMPI & 0 & 0.105 & -0.031 & -0.001 & 0.01 & 230 & \\
\hline & NMMPI & 0 & 0.098 & -0.054 & -0.001 & 0.01 & 230 & \\
\hline \multirow[t]{5}{*}{ Indonesia } & VHH & -1.228 & 3.072 & -6.885 & -0.785 & 1.376 & 271 & 1 \\
\hline & RMPI & -4.423 & 7.314 & -48.022 & -4.085 & 3.979 & 271 & \\
\hline & NMPI & 0.063 & 41.452 & -7.458 & -0.15 & 3.134 & 271 & \\
\hline & RMMPI & -0.038 & 0.025 & -0.215 & -0.024 & 0.04 & 271 & \\
\hline & NMMPI & 0 & 0.115 & -0.059 & -0.001 & 0.014 & 271 & \\
\hline \multirow[t]{5}{*}{ Japan } & VHH & -0.926 & 19.478 & -4.327 & -0.763 & 1.441 & 388 & 1 \\
\hline & RMPI & -5.604 & 2.829 & -50.172 & -3.2 & 6.328 & 388 & \\
\hline & NMPI & 0.117 & 43.066 & -6.697 & -0.012 & 2.796 & 388 & \\
\hline & RMMPI & -0.002 & 0.001 & -0.01 & -0.001 & 0.002 & 388 & \\
\hline & NMMPI & 0 & 0.002 & -0.002 & 0 & 0 & 388 & \\
\hline \multirow[t]{5}{*}{ Korea } & VHH & -1.012 & 13.575 & -5.258 & -0.762 & 1.372 & 383 & 1 \\
\hline & RMPI & -9.222 & 15.794 & -35.366 & -8.735 & 6.08 & 383 & \\
\hline & NMPI & -0.096 & 32.47 & -4.658 & -0.184 & 2.356 & 383 & \\
\hline & RMMPI & -0.044 & 0.079 & -0.181 & -0.037 & 0.036 & 383 & \\
\hline & NMMPI & 0 & 0.134 & -0.026 & 0 & 0.01 & 383 & \\
\hline Malaysia & VHH & -1.775 & 1.563 & -13.506 & -1.239 & 1.450 & 183 & 1 \\
\hline
\end{tabular}




\begin{tabular}{|c|c|c|c|c|c|c|c|c|}
\hline Country & Index & Mean & Max & Min & Median & S.D & $\mathrm{N}$ & Number of crises \\
\hline & RMPI & -22.825 & -0.475 & -89.082 & -11.758 & 23.471 & 183 & \\
\hline & NMPI & 0.269 & 36.948 & -18.293 & -0.016 & 4.373 & 183 & \\
\hline & RMMPI & -0.014 & 0 & -0.071 & -0.011 & 0.013 & 183 & \\
\hline & NMMPI & 0 & 0.031 & -0.033 & 0 & 0.005 & 183 & \\
\hline \multirow[t]{5}{*}{ Mexico } & VHH & -0.396 & 5.771 & -5.999 & -0.122 & 1.431 & 316 & 2 \\
\hline & RMMPI & -5.282 & 6.477 & -72.358 & -2.801 & 10.708 & 316 & \\
\hline & NMMPI & 0.142 & 11.002 & -14.671 & 0.008 & 2.165 & 316 & \\
\hline & RMMPI & -0.02 & 0.019 & -0.108 & -0.013 & 0.02 & 316 & \\
\hline & NMMPI & 0 & 0.093 & -0.021 & 0 & 0.008 & 316 & \\
\hline \multirow[t]{6}{*}{ Philippines } & VHH & -1.523 & 3.820 & -13.054 & -1.186 & 1.491 & 230 & 1 \\
\hline & RMPI & -8.653 & 2.943 & -43.279 & -3.83 & 10.48 & 230 & \\
\hline & NMPI & -0.072 & 11.063 & -7.978 & -0.188 & 1.962 & 230 & \\
\hline & RMMPI & -0.013 & 0.005 & -0.057 & -0.008 & 0.01 & 230 & \\
\hline & NMMPI & 0 & 0.04 & -0.032 & 0 & 0.005 & 230 & \\
\hline & RMPI & -2.564 & 21.27 & -12.883 & -1.655 & 3.564 & 255 & \\
\hline \multirow[t]{4}{*}{ Turkey } & VHH & -0.495 & 6.421 & -9.067 & -0.092 & 1.451 & 255 & 1 \\
\hline & NMPI & 0.074 & 23.182 & -8.574 & -0.081 & 2.763 & 255 & \\
\hline & RMMPI & -0.013 & 0.042 & -0.116 & -0.009 & 0.016 & 255 & \\
\hline & NMMPI & 0 & 0.186 & -0.115 & 0 & 0.019 & 255 & \\
\hline \multirow[t]{5}{*}{ United States } & $\mathrm{VHH}$ & -1.163 & 5.553 & -8.289 & -0.841 & 1.431 & 389 & 2 \\
\hline & RMPI & -8.475 & 59.435 & -63.06 & -6.506 & 10.467 & 389 & \\
\hline & NMPI & 0.321 & 60.412 & -9.103 & 0.118 & 3.56 & 389 & \\
\hline & RMMPI & -0.002 & 0.005 & -0.012 & -0.002 & 0.003 & 389 & \\
\hline & NMMPI & 0 & 0.007 & -0.007 & 0 & 0.001 & 389 & \\
\hline
\end{tabular}


Table 3. Contingency table for concepts in assessing crisis signals

\begin{tabular}{|c|c|c|}
\hline Crises & Identified in the benchmark & Not identified in the benchmark \\
\hline Identified in this paper & Correct crises & False alarms \\
\hline Not identified in this paper & Missed crises & \\
\hline
\end{tabular}


Table 4. Assessing the predictive power of the indices

\begin{tabular}{llcccc}
\hline Index & VHH & RMPI & RMMPI & NMPI & NMMPI \\
\hline Total number of crises in the benchmark & 75 & 75 & 75 & 75 & 75 \\
Correct crises & 40 & 49 & 47 & 53 & 54 \\
Type I error (missed crises) & 35 & 26 & 28 & 22 & 21 \\
Type II error (false alarms) & 181 & 181 & 158 & 218 & 166 \\
Frequency of Type I error & $46.67 \%$ & $34.67 \%$ & $37.33 \%$ & $29.33 \%$ & $28.00 \%$ \\
Frequency of Type II error & $81.90 \%$ & $78.70 \%$ & $77.07 \%$ & $80.44 \%$ & $75.45 \%$ \\
\hline
\end{tabular}

Note: This table shows the predictive power of five monetary pressure indices (see Table 1 for their definition), and zooms in on type I and type II errors in identifying banking crises. "Correct crises" is the number of crises identified correctly according to the benchmark of Laeven and Valencia (2010). 
Table 5.Values of the loss function in Equation (4) for different values of $\left(c_{2}-c_{1}\right)$

\begin{tabular}{cccc}
\hline$\left(c_{2}-c_{1}\right)$ & NMMPI & RMMPI & Difference \\
\hline 5 & 2.339 & 2.300 & 0.039 \\
10 & 2.346 & 2.330 & 0.016 \\
15 & 2.352 & 2.361 & -0.009 \\
20 & 2.358 & 2.392 & -0.034 \\
25 & 2.365 & 2.423 & -0.058 \\
30 & 2.371 & 2.454 & -0.083 \\
35 & 2.377 & 2.487 & -0.110 \\
40 & 2.384 & 2.519 & -0.135 \\
45 & 2.390 & 2.552 & -0.162 \\
50 & 2.397 & 2.585 & -0.188 \\
\hline
\end{tabular}


Table 6. Results for different samples of countries

\begin{tabular}{lcc}
\hline & NMMPI & RMMPI \\
\hline Total crises in the benchmark & Industrial countries & 11 \\
Correct crises & 11 & 8 \\
Type I error (missed crises) & 8 & 3 \\
Type II error (false alarms) & 3 & 24 \\
Frequency of Type I error & 30 & $27.27 \%$ \\
Frequency of Type II error & $27.27 \%$ & $75.00 \%$ \\
\hline & $78.95 \%$ & 64 \\
\hline Total crises in the benchmark & Developing countries & 39 \\
Correct crises & 64 & 25 \\
Type I error (missed crises) & 46 & 134 \\
Type II error (false alarms) & 18 & $39.06 \%$ \\
Frequency of Type I error & 136 & $77.46 \%$ \\
Frequency of Type II error & $28.13 \%$ & $74.73 \%$ \\
\hline
\end{tabular}

Note: See Table 4. 
Table 7. Results for different periods

\begin{tabular}{|c|c|c|c|c|}
\hline Index: & Period: & 1970-1989 & 1990-1999 & $2000-2009$ \\
\hline & $\begin{array}{l}\text { Total crises in the } \\
\text { benchmark }\end{array}$ & 15 & 46 & 14 \\
\hline \multirow{5}{*}{ NMMPI } & Correct crises & 9 & 34 & 11 \\
\hline & Type I error & 6 & 12 & 3 \\
\hline & Type II error & 42 & 54 & 70 \\
\hline & $\begin{array}{l}\text { Frequency of } \\
\text { Type I errors }\end{array}$ & $40.00 \%$ & $26.09 \%$ & $21.43 \%$ \\
\hline & $\begin{array}{l}\text { Frequency of } \\
\text { Type II errors }\end{array}$ & $82.35 \%$ & $61.36 \%$ & $86.42 \%$ \\
\hline \multirow{5}{*}{ RMMPI } & Correct crises & 4 & 33 & 10 \\
\hline & Type I error & 11 & 13 & 4 \\
\hline & Type II error & 20 & 48 & 90 \\
\hline & $\begin{array}{l}\text { Frequency of } \\
\text { Type I errors }\end{array}$ & $73.33 \%$ & $28.26 \%$ & $28.57 \%$ \\
\hline & $\begin{array}{l}\text { Frequency of } \\
\text { Type II errors }\end{array}$ & $83.33 \%$ & $59.26 \%$ & $90.00 \%$ \\
\hline
\end{tabular}

Note: See Table 4.

Table 8. Two types of errors for different crises periods

\begin{tabular}{ccc}
\hline & Missed crises & False alarms \\
\hline NMMPI & 21 & 166 \\
NMMPI with different window & 17 & 161 \\
\hline
\end{tabular}

Note : This table shows the two types of errors for two indices. If there is a crisis at time $T$ in the benchmark, the signal of NMMPI is correct if it falls in the period of $[T-2, T+1]$. In the alternative this period is set at $[T-2, T+2]$. 
Table 9. Robustness test using the benchmark of Reinhart and Rogoff (2009)

\begin{tabular}{|c|c|c|c|c|}
\hline Index: & RMPI & RMMPI & NMPI & NMMPI \\
\hline \multicolumn{5}{|c|}{ Window=12 Months } \\
\hline Total crises in the benchmark & 71 & 71 & 71 & 71 \\
\hline Correct crises & 46 & 42 & 51 & 49 \\
\hline Type I error (missed crises) & 25 & 29 & 20 & 22 \\
\hline Type II error (false alarms) & 194 & 179 & 221 & 167 \\
\hline Frequency of Type I errors & $35.21 \%$ & $40.85 \%$ & $28.17 \%$ & $30.99 \%$ \\
\hline Frequency of Type II errors & $80.83 \%$ & $81.00 \%$ & $81.25 \%$ & $77.31 \%$ \\
\hline \multicolumn{5}{|c|}{ Window=18 Months } \\
\hline Total crises in the benchmark & 71 & 71 & 71 & 71 \\
\hline Correct crises & 43 & 42 & 45 & 49 \\
\hline Type I error (missed crises) & 28 & 29 & 26 & 22 \\
\hline Type II error (false alarms) & 191 & 173 & 230 & 170 \\
\hline Frequency of Type I errors & $39.44 \%$ & $40.85 \%$ & $36.62 \%$ & $30.99 \%$ \\
\hline Frequency of Type II errors & $81.62 \%$ & $80.47 \%$ & $83.64 \%$ & $77.63 \%$ \\
\hline \multicolumn{5}{|c|}{ Window=24 Months } \\
\hline Total crises in the benchmark & 69 & 69 & 69 & 69 \\
\hline Correct crises & 44 & 41 & 43 & 49 \\
\hline Type I error (missed crises) & 25 & 28 & 26 & 20 \\
\hline Type II error (false alarms) & 181 & 160 & 221 & 163 \\
\hline Frequency of Type I errors & $36.23 \%$ & $40.58 \%$ & $37.68 \%$ & $28.99 \%$ \\
\hline Frequency of Type II errors & $80.44 \%$ & $79.60 \%$ & $83.71 \%$ & $76.89 \%$ \\
\hline \multicolumn{5}{|c|}{ Window=30 Months } \\
\hline Total crises in the benchmark & 68 & 68 & 68 & 68 \\
\hline Correct crises & 41 & 38 & 42 & 47 \\
\hline Type I error (missed crises) & 27 & 30 & 26 & 21 \\
\hline Type II error (false alarms) & 180 & 165 & 207 & 160 \\
\hline Frequency of Type I errors & $39.71 \%$ & $44.12 \%$ & $38.24 \%$ & $30.88 \%$ \\
\hline Frequency of Type II errors & $81.45 \%$ & $81.28 \%$ & $83.13 \%$ & $77.29 \%$ \\
\hline \multicolumn{5}{|c|}{ Window=36 Months } \\
\hline Total crises in the benchmark & 65 & 65 & 65 & 65 \\
\hline Correct crises & 40 & 38 & 40 & 45 \\
\hline Type I error (missed crises) & 25 & 27 & 25 & 20 \\
\hline Type II error (false alarms) & 176 & 155 & 209 & 167 \\
\hline Frequency of Type I errors & $38.46 \%$ & $41.54 \%$ & $38.46 \%$ & $30.77 \%$ \\
\hline Frequency of Type II errors & $81.48 \%$ & $80.31 \%$ & $83.94 \%$ & $78.77 \%$ \\
\hline
\end{tabular}

Note: This table shows the results of four indices with the benchmark given by Reinhart and Rogoff (2009). In this table, we show the results with the rolling time window of 12, 18, 24, 30, and 36 months for calculating the standard deviations. "Correct crises" is the number of crises the index identifies correctly according the benchmark. 
Figure 1. MPI and MMPI for different weights for two components

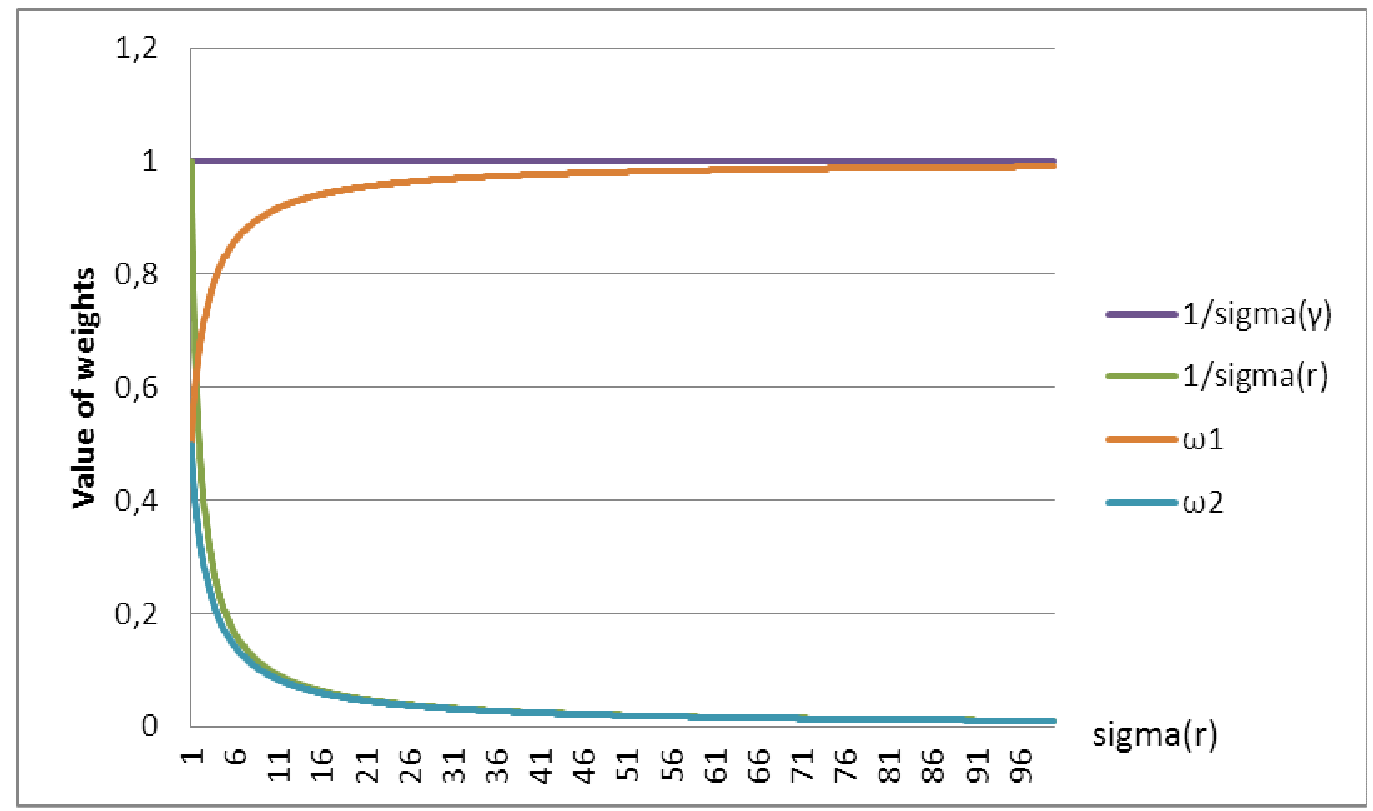

Note: This figure shows the differences between weights in equation (1) and (2). $\operatorname{Sigma}(\gamma)$ and $\operatorname{sigma}(r)$ are the weights in equation (1), and $\omega 1$ and $\omega 2$ are the weights in equation (2). In this figure, we set the value of $\operatorname{sigma}(\gamma)$ to 1 while the value of sigma(r) varies from 1 to 100 . 
Figure 2. Money market pressure indices of money market pressure in 10 countries
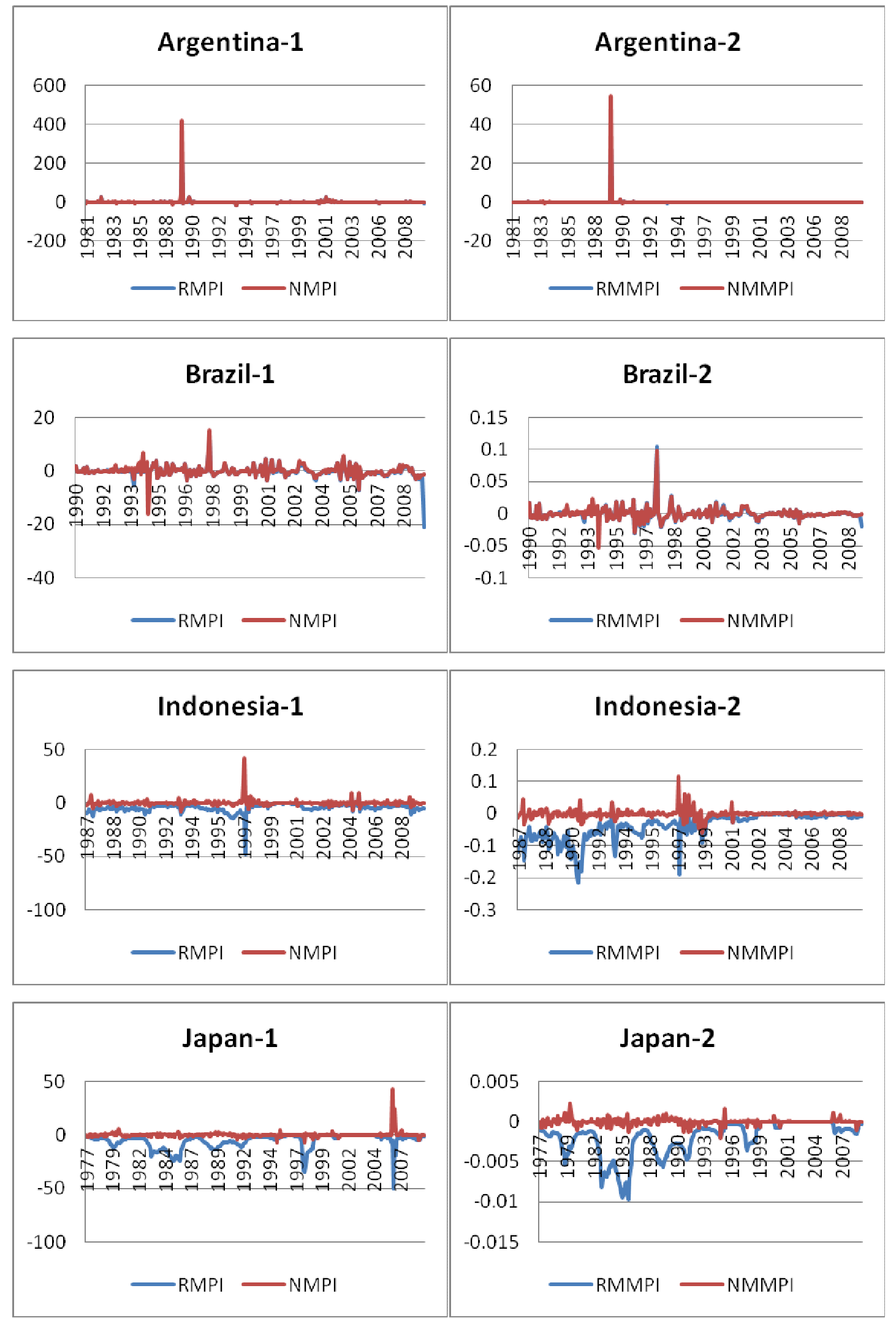

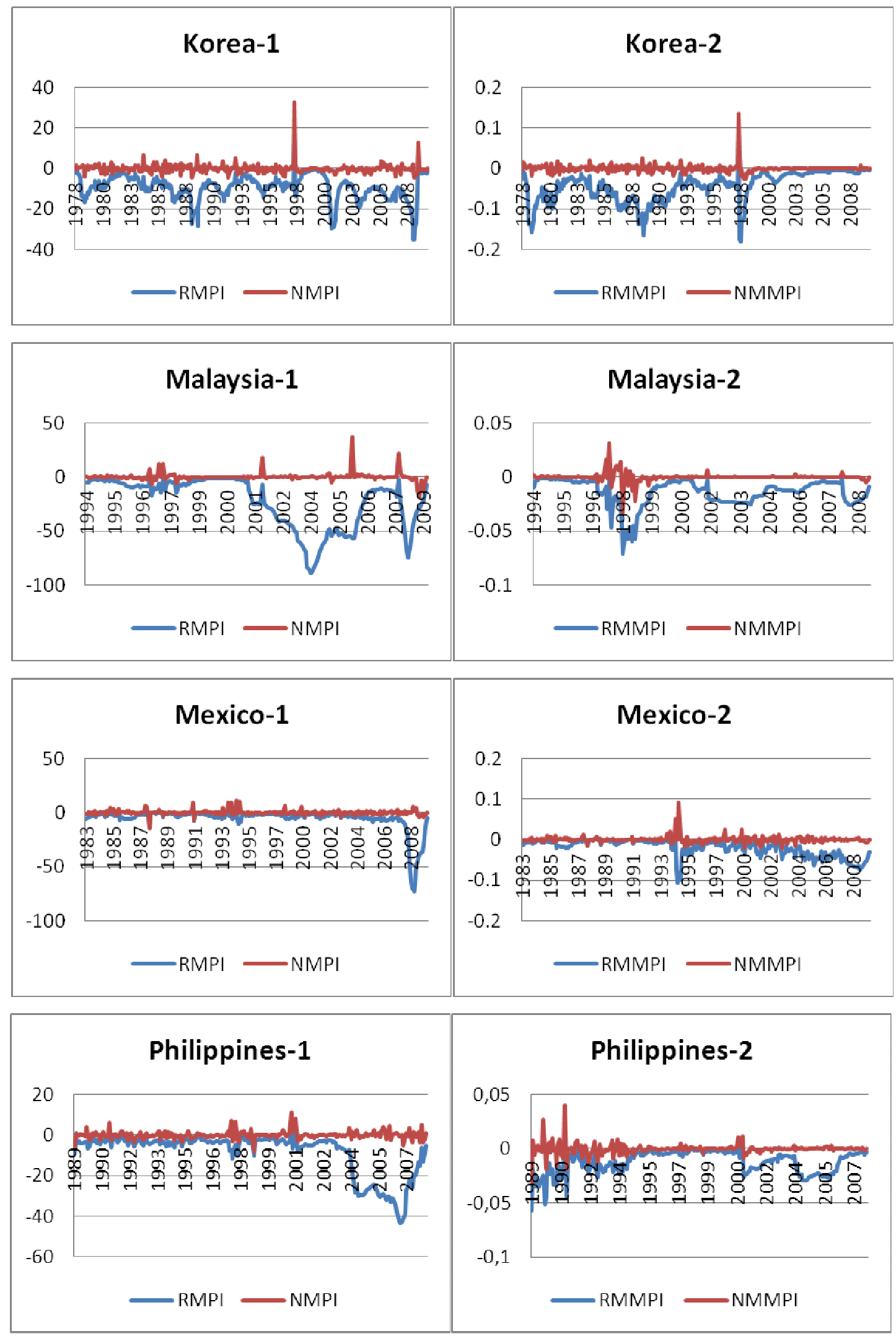

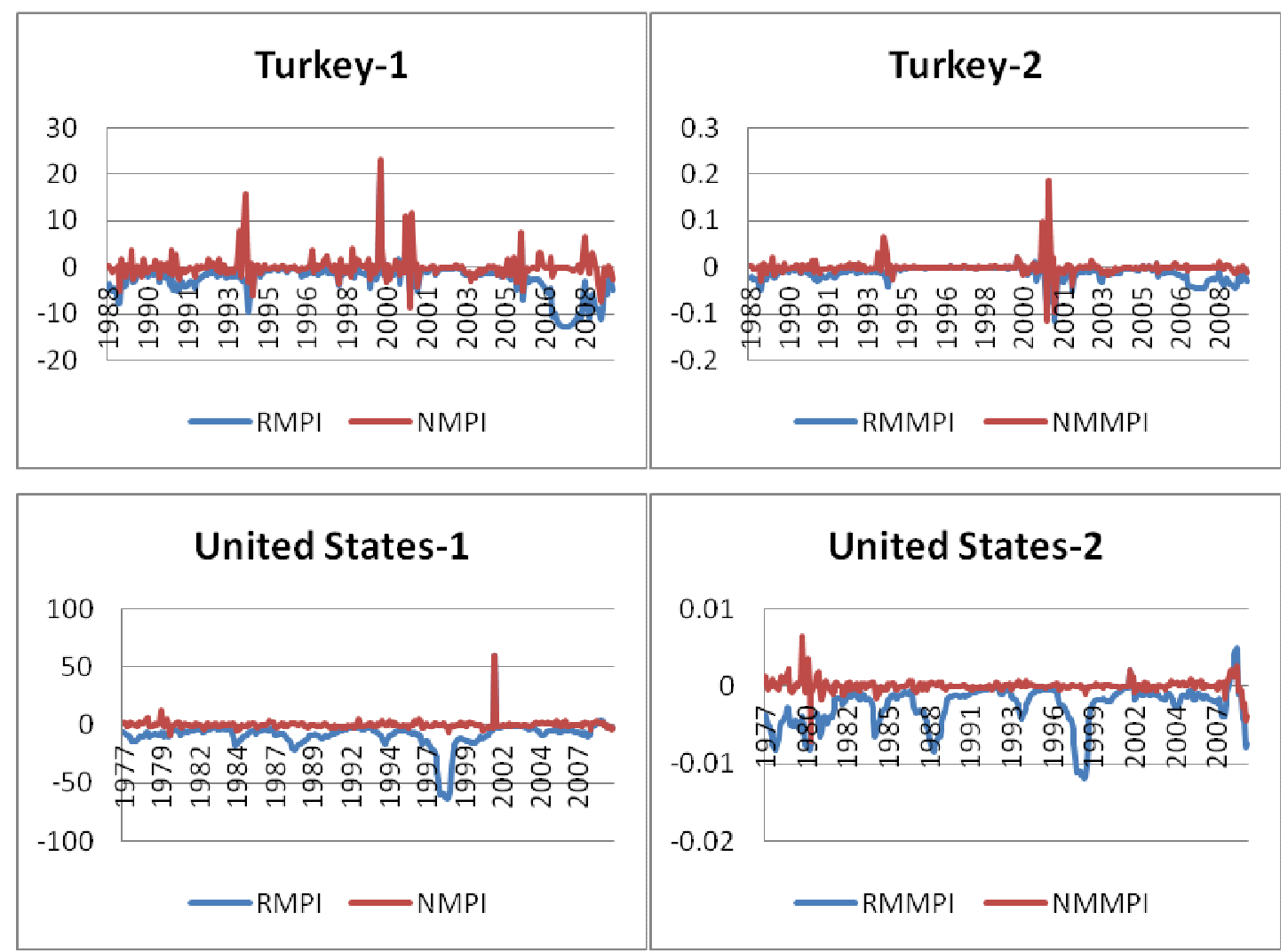

Note: This figure plots four money market pressure indices for the selected countries. The first graph for each country shows RMPI and NMPI constructed according to equation (1), and the second one presents RMMPI and NMMPI constructed according to equation (2). 